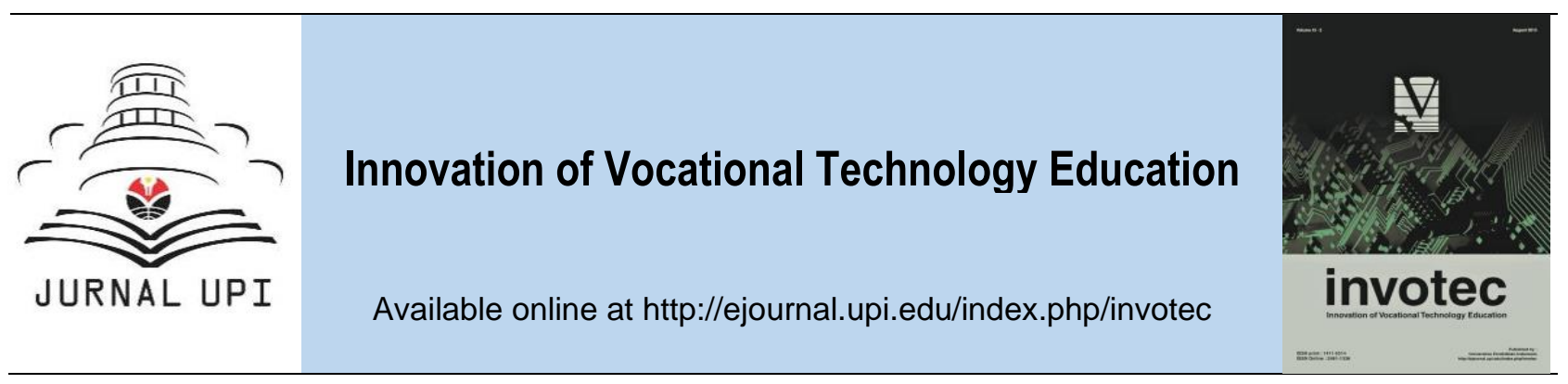

\title{
Analysis of Vocational School Development Based on Regional Potential Using Principal Component Analysis (PCA)
}

Saripudin S and Ida Bagus Budiyanto

Politeknik TEDC, Bandung, Indonesia

\section{ARTICLE INFO}

Article history:

Received: 14 October 2019

Received in revised form: 02 December 2019

Accepted: 20 January 2020

Available online: 29 February 2020

Keywords:

development of SMK;

regional potentials;

Principle Component Analysis (PCA);

Cimahi City

Authors email:

saripudin@poltektedc.ac.id

ibudbudiyanto@poltektedc.ac.id
A B S T R A C T

This study aims to analyze the development of Vocational High School (SMK) based on regional potential in Cimahi City, Indonesia. This study is descriptive research. This study was conducted in Cimahi City, West Java Province, Indonesia. The population and sample of this study were all the potentials of the region and the industrial fields in the City of Cimahi, West Java and the fields/programs/competencies of SMKs in the City of Cimahi. Data in this study were collected using documentation, interview and observation methods. The Principle Component Analysis (PCA) was used as the method of analyzing regional potentials using Minitab Statistical Software version 14. Based on the results of this study it was found that the development of Vocational High Schools is based on regional potential in Cimahi City and based on the analysis of Vocational Development Levels in Cimahi City by using the PCA analysis method based on indicators education such as Total Population Ages 16-18, Student Ratio per School, Student Ratio per Class, Student Ratio per Teacher, and Gross Participation Rate (GPR) in 3 (three) Districts of Cimahi City found that the lowest PCA 1 for the three districts is in South Cimahi District (-1026.02). This means that the priority location I for the development of SMK is South Cimahi District. It is then followed by Central Cimahi Subdistrict (-644.19) which becomes priority location II for the development of SMK. And Priority III is the District of North Cimahi (-435.5). With these findings, the Office of Education, especially in the area of Vocational Secondary Education in the Cimahi City, West Java, should pay attention to the development of vocational schools which requires careful study in establishing vocational schools based on the potential of the region.

\section{Introduction}

BPS data released in 2019 stated that the number of unemployment at the open unemployment rate (TPT) as of February 2019 was 6.82 million people, or decreased by 50,000 compared to February 2018 , which was 6.87 million people. The number of the unemployed, which is equal to $5.01 \%$ of the total workforce of 136.18 million people, is from vocational high school (VOCATIONAL SCHOOL) graduate, followed by diploma I, II, and III, then high school. Based on 
2019 BPS data, the unemployment rate based on education is still held by vocational graduates, which amounts to $8.63 \%$. Then, diploma I / II / III graduates at $6.89 \%$, high school graduates at $6.78 \%$, and university graduates at $6.24 \%$. Then junior high school graduates at $5.04 \%$ and elementary school graduates at $2.65 \%$. Unemployment in Indonesia is still a major development problem. From the above data it can be seen that the lowest unemployment rate based on education is elementary school graduates.

Meirawan, Ana, and Saripudin (2018) argue that the high unemployment rate is caused by the lack of available jobs, in addition to the inadequate quality of vocational graduates in the industrial world both in terms of knowledge, skills and attitudes. The type of expertise that graduates with the job market demand is not yet suitable due to the finding of various obstacles, one of which is the perceived constraints of problems that arise in the learning process, such as lack of competency of students, lack of support for school facilities and infrastructure. Continual improvement in the learning process must continue to be pursued. One of the steps taken to improve the quality of learning is to evaluate the learning program (Sudjani, 2016).

With the above conditions, the government policy to improve the quality of vocational school graduates to be ready to work (Mayuni \& Sukerti, 2016) revealed that for the government, there should not be partial measures in helping vocational schools in improving the quality of their graduates. It seems that concrete steps are needed to regulate the business and industrial world in order to assist vocational schools in implementing joint programs in an effort to prepare a ready workforce. Preparation of rules or even laws that bind all business and industry sectors in realizing this collaboration. DUDI nationalism is built by starting from making laws and rules that bind them towards the direction of building a strong nation.

In addition, organizing of vocational schools is not built based on the potential and location of the region (Meirawan, Ana, \& Saripudin, 2018), thus the location of vocational schools is not centered at one point, the location of the school must not be far from educational activities, settlements, and access to transportation to enable students to easily access it. School locations must also be supported by strategic regional conditions in the hope of supporting learning in order to produce quality graduates.

For this reason, it is important for the government to reorganize education planning in order to improve the quality of education (Enoch, 1995). Vocational planning based on regional potentials is expected to bring vocational graduates to work in cities / districts based on the potential of their respective regions. Regional potential can have more economic value if there are human resources who are able to manage it well. Improving the quality and relevance of education is a government policy in improving the quality of Indonesian human resources in line with changes in the education and business world, and professionalism in all fields including education is needed. Increasing the relevance of education is a policy aimed at making education output more oriented towards meeting the working world and the needs of the business and industrial world. Therefore, the relevance of formal and non-formal education processes needs to be directed so that students, both at the 
secondary education level, especially vocational and at the tertiary level, are better prepared to enter the workforce.

Article 31 of the Indonesian 1945 Constitution concerning the national education system states that the national education system must always be developed in accordance with the needs and developments that occur at the local, national and global level. Thus, education is considered as a means of forming quality human resources, and the government needs to do comprehensive planning involving economic, population, educational and potential natural resource indicators.

Vocational education is education that prepares students to work in certain fields (National Education System Law No 20 Tahun 2003). In addition, the Vocational High School is a national education system with its main task preparing graduates to enter the workforce, filling the needs of intermediate skilled workers. Permendiknas No. 29 of 1990 Article 1 paragraph 3 states that, Vocational Education is education at a secondary level that prioritizes developing the ability of students to carry out certain types of work. For this reason, in relation to regional potential development, there needs to be harmony between regional potential development policies and increasing human resources, so that the application of policies prioritizes vocational high schools that can accommodate school-age population by developing regions and carrying out development in their respective regions.

Amalia (2018) revealed the results of research conducted in Medan that there were several factors of vocational education (VOCATIONAL SCHOOL) that could support regional development planning in Medan including: (a) the number of vocational students indicating community interest or junior high school graduates to continue their education to the VOCATIONAL SCHOOL level, (b) the number of VOCATIONAL SCHOOL units for junior high school graduates, (c) the quality of VOCATIONAL SCHOOL graduates to be able to compete in the labor market, and (d) the business / industrial world (DUDI) that accepts VOCATIONAL SCHOOL graduates in the labor market. With the above problems, this research is expected to be able to analyze the development of Vocational High Schools based on regional potential, so that graduates of Vocational High Schools can be directed to develop their respective regions.

Therefore, this research is directed to conduct a study of the development of regional-based VOCATIONAL SCHOOL potential using the Principal Component Analysis (PCA) method. PCA is to establish priority handling of matters that are more basic than the structure of the problems faced, so that the efficiency and effectiveness of problem handling can be further improved. PCA is used as an analysis of determining priorities for the development of vocational schools. With the PCA method, based on the education indicators of each sub-district used, it is possible to know the location in the sub-district where vocational schools are prioritized. 


\section{Methods}

The research method used in this research is the qualitative description method. The qualitative approach was chosen in this study because of several considerations, including: (1) This research is an attempt to find problems related to the condition of vocational schools and how they relate to the development of vocational schools based on the development of regional potential. (2) This research is more inductive, meaning that researchers tried to find problems based on data and were open to further research. (3) This research is conducted in a reasonable situation and prioritizes qualitative data.

\section{Results and Discussion}

\subsection{Cimahi city overview}

The city of Cimahi is geographically located between 107030 '30 " - 107034 '30 " BT and 60 50 " 60 " 6056 '00 " South Latitude. The total area of Cimahi City is 40.2 km2 according to Law No. 9 of 2001 with its territorial boundaries: North Side (Parongpong District, Cisarua District, and Ngamprah District West Bandung Regency), East Side (Sukasari District, Sukajadi District, Cicendo District and Andir District of Bandung City), South Side (Margaasih District Bandung, Batujajar District, West Bandung Regency, and Bandung Kulon District, Bandung City and West Side (Padalarang District, Batujajar District and Ngamprah District, West Bandung Regency).

Cimahi City is included in the area of West Java Province and includes 3 Subdistricts consisting of 15 smaller subdistricts, namely: North Cimahi Subdistrict consists of 4 smaller subdistricts, Central Cimahi Subdistrict consists of 6 smaller subdistricts and South Cimahi Subdistrict consists of 5 smaller subdistricts. Geographically this region is a basin valley that slopes to the south, with an altitude in the north $\pm 1,040$ meters above sea level (Cipageran Village, North Cimahi District), which is the slope of Mount Burangrang and Mount Tangkuban Perahu and height in the south is around \pm 685 meters above sea level (as high as Melong Village, Cimahi Selatan District) which leads to the Citarum River. The river that passes through Cimahi City is the Cimahi River, with five tributaries, namely Cibodas River, Ciputri, Cimindi, Cibeureum and Cisangkan River, while the springs found in Cimahi City are Cikuda springs and Cisintok springs. 


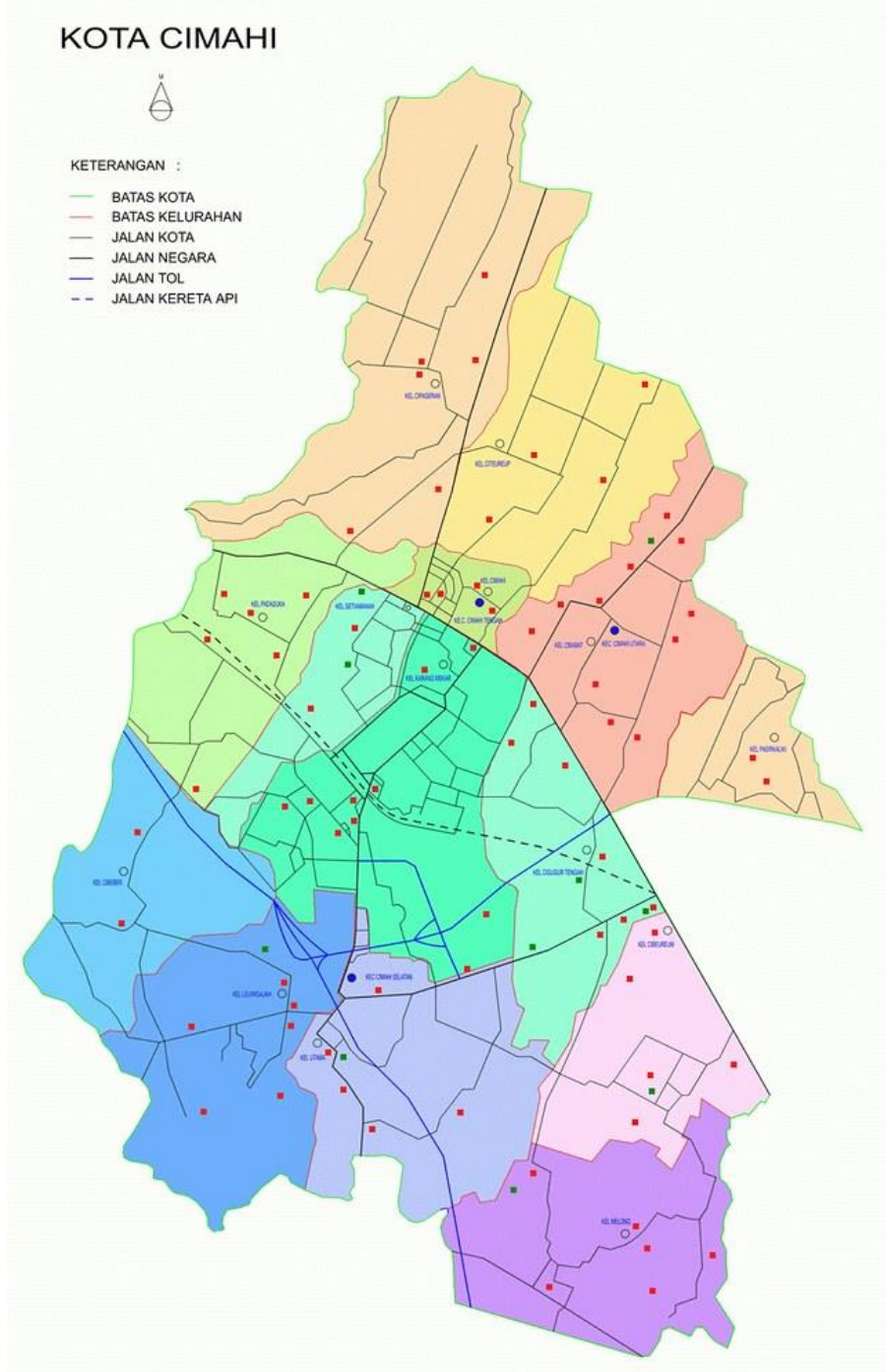

Figure 1. Cimahi city map

3.1.1 Potential of agriculture, animal husbandry and fisheries of Cimahi City City of Cimahi's Agricultural Business is divided into several parts, which are:

- Agriculture Business by Form: a) Large Agriculture is agriculture that is organized (managed) commercially by a legal entity, b) People's Agriculture (not incorporated), consisting of:

- People's Agriculture Business is an agricultural business that is organized or managed commercially by an individual business that is not notarized.

- Agricultural Household Business is an agricultural business organized or managed by an agricultural household.

- Agricultural Business by Sub Sector.

- Food Crop Agriculture is an agricultural business activity that produces food crop production, namely: Rice, Food Crops and Horticulture.

- Plantation Plant Agricultural Business is an agricultural activity that produces plantation production, such as rubber, coffee, tea, pepper, clove, etc. (BPS Cimahi City 2018). 
In the City of Cimahi, food crops include vegetables, fruits and vegetables. Food plants consist of grains, corn, tubers and beans. Food crop data is broken down according to harvested area, yields per hectare and production. The area of paddy fields using semi-technical irrigation in 2015 was 106.42 hectares. While the area of dry land when viewed according to its use, the type of yard / land for buildings and courtyards reaches 714 hectares or 71.90 percent of the total dry land. Followed by tegal / gardens / fields / huma 279 hectares or 28.10 . For rice production in 2015 , decreased from 27,291.2 quintals to 7,135 quintals, rice productivity also decreased from 55.58 quintals / ha to 27.23 kwt / ha. Below table 1 and 2 shows Harvest Area and Average Production of Paddy Rice by District in 2016 and Average Crop Production by District in 2016.

Table 1. Harvested area and average production of paddy rice (According to the district of 2016)

\begin{tabular}{|c|c|c|c|c|c|}
\hline \multirow{2}{*}{ No. } & \multirow[b]{2}{*}{ District } & \multicolumn{2}{|c|}{ Area } & \multirow[b]{2}{*}{$\begin{array}{l}\text { Production } \\
\text { (Kwt) }\end{array}$} & \multirow{2}{*}{$\begin{array}{c}\text { Production } \\
\text { Average } \\
\text { (Kwt/Ha) }\end{array}$} \\
\hline & & $\begin{array}{c}\text { Planting } \\
(\mathrm{Ha})\end{array}$ & $\begin{array}{c}\text { Harvest } \\
(\mathrm{Ha})\end{array}$ & & \\
\hline 1 & South Cimahi & 92 & 93 & 5.776 & 62 \\
\hline 2 & Central Cimahi & 13 & 20 & 1300 & 65 \\
\hline \multirow[t]{2}{*}{3} & North Cimahi & 149 & 149 & 69 & 0,56 \\
\hline & & 254 & 262 & 7.135 & 27,23 \\
\hline
\end{tabular}

Source: BPS Cimahi City 2018 (Data processing)

Table 2. Average crop production (According to the district of 2016)

\begin{tabular}{|c|c|c|c|c|c|c|c|c|c|}
\hline \multirow{2}{*}{ No. } & \multirow{2}{*}{ District } & \multicolumn{8}{|c|}{$\begin{array}{c}\text { Production Average (Kwt/Ha) } \\
\text { Production (Kwt) }\end{array}$} \\
\hline & & Rice & Corn & Cassava & $\begin{array}{l}\text { Sweet } \\
\text { Potato }\end{array}$ & Tomato & Mustard & Banana & Rambutan \\
\hline 1 & $\begin{array}{l}\text { South } \\
\text { Cimahi }\end{array}$ & 62 & 2,88 & 170 & 110 & 0 & 120 & 610 & 250 \\
\hline 2 & $\begin{array}{l}\text { Central } \\
\text { Cimahi }\end{array}$ & 65 & 3,54 & 180 & 110 & 0 & 0 & 0 & 0 \\
\hline 3 & $\begin{array}{l}\text { North } \\
\text { Cimahi }\end{array}$ & 0,46 & 3,45 & 160 & 110 & 20 & 120 & 37,5 & 325 \\
\hline
\end{tabular}

Source: BPS Cimahi City in 2018 (Data analysis)

Cimahi farms include beef cattle, buffaloes, dairy cows, horses, sheep and goats. The most livestock raised are sheep, amounting to 13,487 . While the fewest cattles are buffaloes, at 24 . In addition, poultry livestock data also included poultry, broilers, laying hens and ducks. In 2015, there were 35,381 domestic poultry, 82,122 broiler, 11,719 ducks. In 2015 all types of livestock experienced a decline in population except ducks. The following table 3, Number of Livestock (Tails) by Sub-district 2016 below: 
Table 3. Number of cattle (According to the district of 2016)

Average Cattle Production

\begin{tabular}{cccccccccc} 
No. & District & $\begin{array}{c}\text { Beef } \\
\text { Cattle }\end{array}$ & $\begin{array}{c}\text { Dairy } \\
\text { Cows }\end{array}$ & Buffalo & Sheep & Horse & Chicken & Duck & Goat \\
\hline 1 & $\begin{array}{c}\text { South } \\
\text { Cimahi }\end{array}$ & 50 & 0 & 4 & 7657 & 460 & 11038 & 5.375 & 58 \\
2 & $\begin{array}{c}\text { Central } \\
\text { Cimahi }\end{array}$ & 18 & 25 & 2 & 1715 & 0 & 8650 & 1.955 & 0 \\
3 & $\begin{array}{c}\text { North } \\
\text { Cimahi }\end{array}$ & 57 & 842 & 15 & 4.385 & 166 & 16400 & 4.623 & 104 \\
\hline
\end{tabular}

Source: BPS Cimahi City 2018 (Data analysis)

Fisheries in Cimahi City consist of ponds and rice fields. In 2015 the pond is the largest fish rearing place, which is 100 percent of the total area of rearing fish (Source: BPS City of Cimahi 2018). The following table 4 shows the area of fisheries according to sub-districts in 2016 below:

Table 4. Area of fisheries (According to the district of 2016)

\begin{tabular}{llll}
\hline \multirow{2}{*}{ No. } & \multirow{2}{*}{ District } & \multicolumn{2}{l}{ Area } \\
\cline { 3 - 4 } & & Pond (Ha) & Paddy (Ha) \\
\hline 1 & South Cimahi & 2,07 & 0 \\
2 & Central Cimahi & 1,54 & 0 \\
3 & North Cimahi & 3,14 & 0 \\
\hline \multicolumn{3}{c}{ Source: BPS Cimahi City 2018 (Data analysis) }
\end{tabular}

\subsubsection{Industrial potential of Cimahi City}

The biggest contribution to economic development in Cimahi City in 2014 was dominated by the manufacturing industry sector. The data source of this industrial sector was obtained from the results of an annual survey of large / medium industrial companies. In collecting industrial statistics, what is meant by large industries are companies with 100 or more workers, medium industries are have between 20 and 99 people, while small industries have between 5 and 19 people, and companies that have less workers than 5 people are called household businesses. The number of industrial companies in 2014 consisted of 63 large industries and 67 medium industries.

The largest number of large / medium industry companies are in the South Cimahi subdistrict, which is 95 companies (73.08\%). While the least were district of North Cimahi district, with 15 companies (9.2\%). Electricity both for industry and households in Cimahi City are mostly sourced from the state electricity company (PLN) and some from outside PLN. In 2015 the number of families who enjoyed electricity flow from PLN lighting sources was 200,302 families. The electricity supplied by PLN per month reached 1,248 million Kwh / VA. Clean water in Cimahi City is sourced from PDAM 
Cimahi City. And every month the need for clean water averages to $245,768 \mathrm{~m} 3$. The volume of water channeled during 2015 was 2,949,563 m3, and the biggest consumers were in the household amounting to $2,262,902 \mathrm{~m} 3$ or 76.72 percent. The following table 5 below shows the data of the number of large and medium industries by district in 2016 .

Table 5. Large and medium industries (According to the district of 2016)

\begin{tabular}{ccccc}
\hline \multirow{2}{*}{ No. } & \multirow{2}{*}{ District } & \multicolumn{3}{c}{ Number of Industries } \\
\cline { 3 - 5 } & & Small & Medium & Large \\
\hline 1 & South Cimahi & 0 & 2,07 & 48 \\
2 & Central Cimahi & 0 & 1,54 & 15 \\
3 & North Cimahi & 0 & 3,14 & 0 \\
\hline & & Source: BPS Cimahi City 2018
\end{tabular}

\subsection{Findings of potential analysis of Cimahi City area}

To find out the potential level of the Cimahi City area, the PDRB component of Cimahi City is used on the basis of Constant Price in 2010 According to Business Field (Million Rupiah), 2016-2017 Cimahi City and West Java, the value weighing was done using the Location Quotient (LQ) analysis method. For details on calculating LQ analysis, regional potential for GRDP, see Table 6 below:

Table 6. LQ Analysis on Cimahi City GRDP based on 2010 Constant prices according to business field (million rupiah), 2017

\begin{tabular}{|c|c|c|c|c|c|}
\hline Category & Description & Cimahi City & West Java & $\mathbf{L Q}$ & Criteria \\
\hline A & $\begin{array}{c}\text { Agriculture, Forestry and } \\
\text { Fisheries }\end{array}$ & $33,087.96$ & $99,874.97$ & 0.024888 & $\begin{array}{l}\text { Non } \\
\text { Basis }\end{array}$ \\
\hline B & Mining and excavation & - & $26,589.93$ & 0 & $\begin{array}{l}\text { Non } \\
\text { Basis }\end{array}$ \\
\hline C & Processing industry & $8,272,746.66$ & $578,858.48$ & 1.073642 & Basis \\
\hline D & $\begin{array}{l}\text { Electricity and Gas } \\
\text { Procurement }\end{array}$ & $45,410.97$ & $5,438.11$ & 0.627329 & $\begin{array}{l}\text { Non } \\
\text { Basis }\end{array}$ \\
\hline$E$ & $\begin{array}{c}\text { Water Supply, Waste } \\
\text { Management, Waste and } \\
\text { Recycling }\end{array}$ & $9,929.54$ & $1,080.96$ & 0.690084 & $\begin{array}{l}\text { Non } \\
\text { Basis }\end{array}$ \\
\hline $\mathrm{F}$ & Construction & $2,318,046.31$ & $111,001.03$ & 1.568835 & Basis \\
\hline $\mathrm{G}$ & $\begin{array}{c}\text { Wholesale and retail trade, car } \\
\text { and motorcycle repair }\end{array}$ & $3,166,136.83$ & $207,945.89$ & 1.14383 & Basis \\
\hline $\mathrm{H}$ & $\begin{array}{c}\text { Transportation and } \\
\text { Warehousing }\end{array}$ & $620,423.59$ & $64,258.58$ & 0.725336 & $\begin{array}{l}\text { Non } \\
\text { Basis }\end{array}$ \\
\hline I & $\begin{array}{l}\text { Provision of Accommodation } \\
\text { and Food and Drink }\end{array}$ & $212,942.22$ & $35,285.42$ & 0.453366 & $\begin{array}{l}\text { Non } \\
\text { Basis }\end{array}$ \\
\hline $\mathrm{J}$ & $\begin{array}{l}\text { Information and } \\
\text { Communication }\end{array}$ & $1,063,886.57$ & $53,527.16$ & 1.49315 & Basis \\
\hline K & $\begin{array}{c}\text { Financial Services and } \\
\text { Insurance }\end{array}$ & $534,228.45$ & $34,179.94$ & 1.174189 & Basis \\
\hline L & Real Estate & $157,799.92$ & $16,109.92$ & 0.735861 & $\begin{array}{l}\text { Non } \\
\text { Basis }\end{array}$ \\
\hline $\mathrm{M}, \mathrm{N}$ & Company Services & $29,773.37$ & $5,784.33$ & 0.386685 & $\begin{array}{l}\text { Non } \\
\text { Basis }\end{array}$ \\
\hline
\end{tabular}


Table 6. Cont.

\begin{tabular}{|c|c|c|c|c|c|}
\hline Category & Description & Cimahi City & West Java & $\mathbf{L Q}$ & Criteria \\
\hline $\mathrm{O}$ & $\begin{array}{c}\text { Government Administration, } \\
\text { Defense and Mandatory Social } \\
\text { Security }\end{array}$ & $394,041.50$ & $25,780.58$ & 1.148237 & Basis \\
\hline $\mathrm{P}$ & \multirow{2}{*}{$\begin{array}{c}\text { Educational Services } \\
\text { Health Services and Social } \\
\text { Activities }\end{array}$} & $617,436.23$ & $37,909.72$ & 1.223556 & Basis \\
\hline Q & & $142,634.98$ & $10,537.79$ & 1.016854 & Basis \\
\hline \multirow[t]{2}{*}{$\mathrm{R}, \mathrm{S}, \mathrm{T}, \mathrm{U}$} & Other services & $257,817.33$ & $28,790.56$ & 0.672735 & $\begin{array}{l}\text { Non } \\
\text { Basis }\end{array}$ \\
\hline & $\begin{array}{c}\text { GROSS REGIONAL } \\
\text { DOMESTIC PRODUCT }\end{array}$ & $17,876,342.43$ & $1,342,953.37$ & & \\
\hline
\end{tabular}

Based on table 6 above, the results of the LQ analysis found that Cimahi City has basic criteria (LQ> 1), namely in the manufacturing, construction, wholesale and retail sectors, car and motorcycle repair, information and communication, financial and insurance services, administration government, defense and mandatory social security, education services, and health services and social activities.

\subsection{Field analysis, programs and vocational expertise competencies in Cimahi City}

The number of VOCATIONAL SCHOOLs in Cimahi City is 24 schools with 106 skills competencies. There are 3 State Vocational Schools in Cimahi City and 21 Private Vocational Schools. While the number of High Schools in Cimahi City is 16 Schools consisting of 6 Public High Schools and 10 Private High Schools. The following table 7 shows the distribution of the number of high schools and vocational schools in the City of Cimahi.

Table 7. Distribution of the number of high schools and vocational schools in Cimahi City in 2019

\begin{tabular}{cccccc}
\hline \multirow{2}{*}{ No } & \multirow{2}{*}{ District } & \multicolumn{2}{c}{ Vocational Schools } & \multicolumn{2}{c}{ High Schools } \\
\cline { 3 - 6 } & Public & Private & Public & Private \\
\hline 1 & South Cimahi & 1 & 7 & 2 & 3 \\
2 & Central Cimahi & 0 & 4 & 3 & 4 \\
3 & North Cimahi & 2 & 10 & 1 & 3 \\
\hline & Total & 3 & 21 & 6 & 10 \\
\hline
\end{tabular}

Source: Survey and data processing from http://dapo.dikdasmen.kemdikbud.go.id/

Based on survey results and data from http://dapo.dikdasmen.kemdikbud.go.id/ in 2019 and referring to the 2018 Vocational Spectrum, the distribution of vocational skills in Cimahi City can be seen in Table 8 below: 
Table 8. Distribution of expertise areas, vocational programs and vocational expertise competencies in Cimahi City in 2019

\begin{tabular}{|c|c|c|c|c|c|}
\hline \multirow{2}{*}{ Field of Expertise / Expertise Program } & \multicolumn{3}{|c|}{$\begin{array}{l}\text { Expertise Competence } \\
(\mathrm{KK})\end{array}$} & \multirow{2}{*}{ Total } & \multirow{2}{*}{ Percentage } \\
\hline & $\begin{array}{l}\text { South } \\
\text { Cimahi }\end{array}$ & $\begin{array}{l}\text { Central } \\
\text { Cimahi }\end{array}$ & $\begin{array}{l}\text { North } \\
\text { Cimahi }\end{array}$ & & \\
\hline \multicolumn{6}{|l|}{ 1. Technology and Engineering } \\
\hline a. Electrical Engineering & 7 & 4 & 1 & \multirow{7}{*}{40} & \multirow{7}{*}{$37.74 \%$} \\
\hline b. Automotive Engineering & 2 & 6 & 2 & & \\
\hline c. Mechanical Engineering & 2 & 1 & 3 & & \\
\hline d. Electrical Engineering & 3 & 3 & 1 & & \\
\hline e. Industrial Instrumentation Engineering & 1 & 0 & 0 & & \\
\hline f. Chemical Engineering & 0 & 0 & 4 & & \\
\hline Total & 15 & 14 & 11 & & \\
\hline \multicolumn{6}{|l|}{ 2. Health and Social Work } \\
\hline a. Pharmacy & 1 & 0 & 2 & \multirow{3}{*}{5} & \multirow{3}{*}{$4.72 \%$} \\
\hline b. Nursing & 1 & 0 & 1 & & \\
\hline Total & 2 & 0 & 3 & & \\
\hline 3. Business and Management & & & & 23 & $21.70 \%$ \\
\hline a. Office Management & 4 & 1 & 6 & & \\
\hline b. Business and Marketing & 1 & 0 & 4 & & \\
\hline c. Commerce & 1 & 0 & 0 & & \\
\hline d. Finance and Accounting & 1 & 1 & 4 & & \\
\hline Total & 7 & 2 & 14 & & \\
\hline \multicolumn{6}{|l|}{ 4. Hospitality } \\
\hline a. Fashion & 1 & 0 & 0 & \multirow{5}{*}{6} & \multirow{5}{*}{$5.66 \%$} \\
\hline b. Hotel Accommodation & 0 & 1 & 0 & & \\
\hline c. Hospitality and Tourism Services & 0 & 0 & 2 & & \\
\hline d. Culinary & 0 & 0 & 2 & & \\
\hline Total & 1 & 1 & 4 & & \\
\hline \multicolumn{6}{|l|}{ 5. Hospitality } \\
\hline a. Hospitality and Tourism Services & 0 & 0 & 2 & \multirow[t]{2}{*}{2} & \multirow[t]{2}{*}{$1.89 \%$} \\
\hline Total & 0 & 0 & 2 & & \\
\hline \multicolumn{6}{|l|}{ 6. Arts and Creative Industries } \\
\hline a. Broadcasting and Film & 1 & 0 & 0 & \multirow{3}{*}{3} & \multirow{3}{*}{$2.83 \%$} \\
\hline b. Arts & 0 & 0 & 2 & & \\
\hline Total & 1 & 0 & 2 & & \\
\hline \multicolumn{6}{|l|}{ 7. Informatics and Information Engineering } \\
\hline a. Computer and Information Engineering & 10 & 2 & 13 & \multirow{3}{*}{27} & \multirow{4}{*}{$25.47 \%$} \\
\hline b. Telecommunications Engineering & 0 & 0 & 2 & & \\
\hline Total & 0 & 2 & 15 & & \\
\hline Total & 36 & 19 & 51 & 106 & \\
\hline
\end{tabular}

Source: Survey and data processing from http://dapo.dikdasmen.kemdikbud.go.id/

Based on table 8 above about the distribution of vocational expertise in Cimahi City in 2019, the most popular technology and engineering expertise was 37.74\% (40 Expertise Competencies), followed by the Informatics and Information Engineering expertise at $25.47 \%$ (27 KK), Business and Management at 21.70\% (23 households), Tourism at 5.66\% (6 households), Health and Social Work at $4.72 \%(5 \mathrm{KK})$, Arts and Creative Industries at $2.83 \%(3 \mathrm{KK})$ and Hospitality at $1.89 \%(2 \mathrm{KK})$

As for the distribution of areas of expertise / program expertise / Competency Expertise based on each district in the city of Cimahi can be seen in Figure 2 below: 


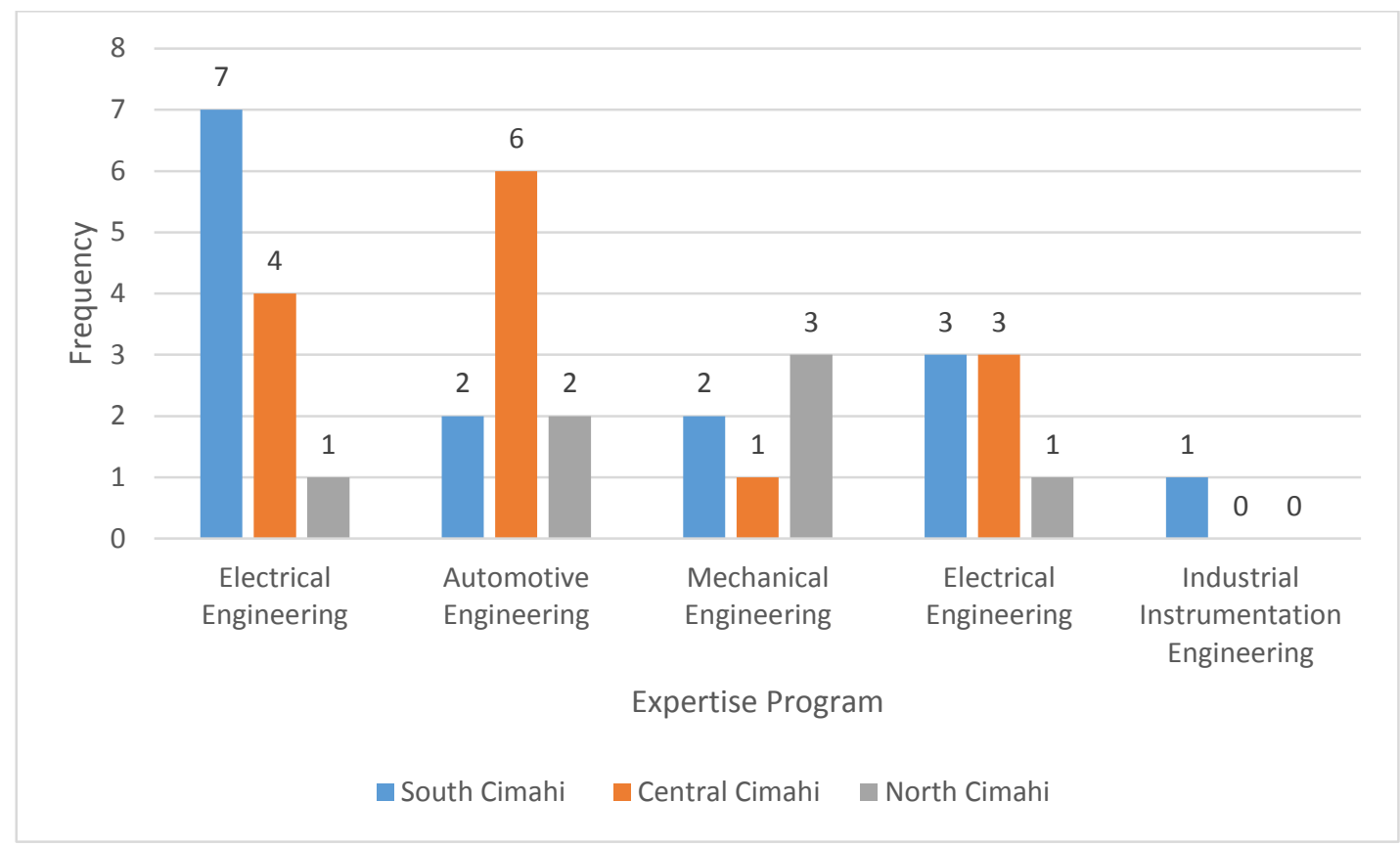

Source: Survey and data from http://dapo.dikdasmen.kemdikbud.go.id/)

Figure 2. Distribution of vocational technology and engineering expertise in Cimahi City in 2019

Vocational Technology and Engineering Expertise in South Cimahi subdistricts is Electronic Engineering expertise ( $7 \mathrm{KK})$, in Central Cimahi subdistrict it is automotive engineering expertise (7 KK) while in North Cimahi subdistrict it is Mechanical Engineering expertise (3 KK). Vocational Information and Communication Technology Expertise in Cimahi subdistrict can be seen in Figure 3 below.

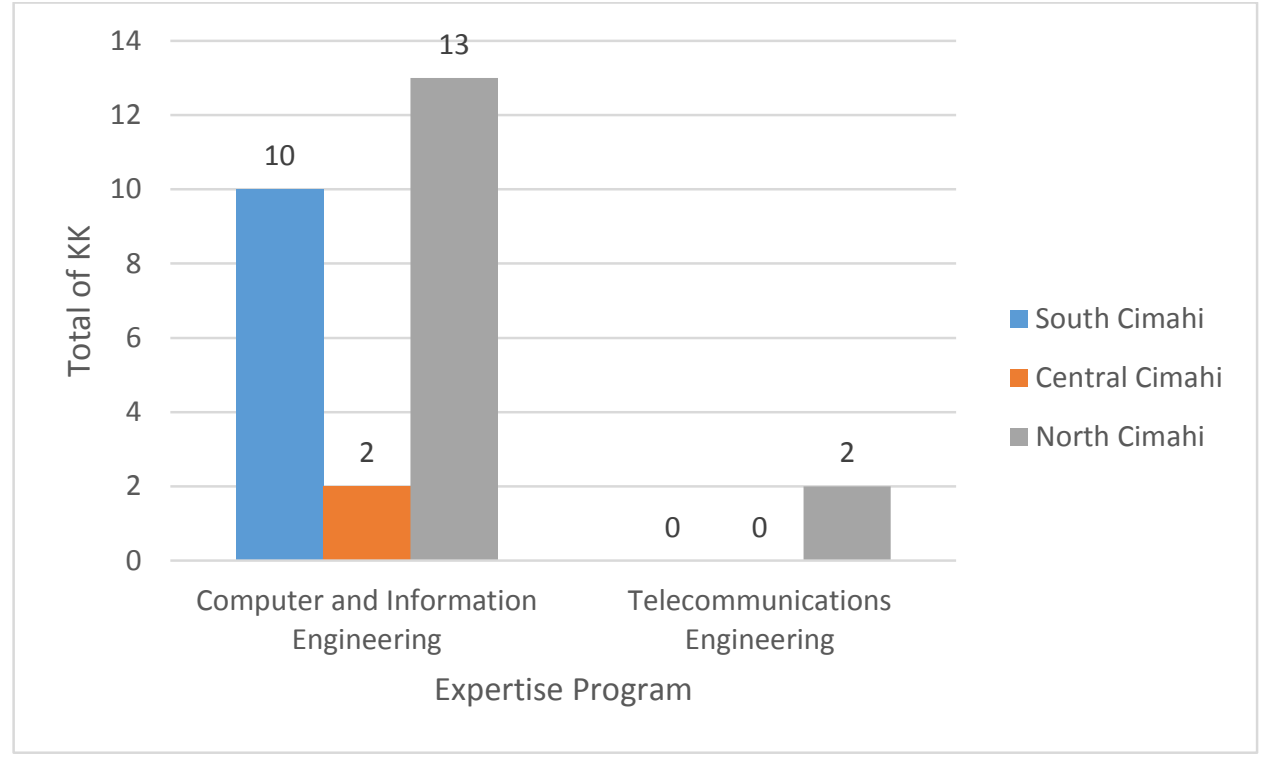

Source: Survey and data from http://dapo.dikdasmen.kemdikbud.go.id// Figure 3. Distribution of expertise competencies in the field of information and communication technology expertise in Cimahi City vocational school (District) 
In the picture above, the Information and Communication Technology Expertise of Vocational Schools in South Cimahi subdistricts is Computer and Information Engineering (10 KK) expertise, in the Cimahi Tengah subdistrict it is the Computer and Information Engineering ( $2 \mathrm{KK}$ ) expertise, whereas in North Cimahi subdistrict it is Telecommunications Engineering expertise (2 KK).

The Vocational Business Management Skills Field in Cimahi subdistrict can be seen in Figure 4 below:

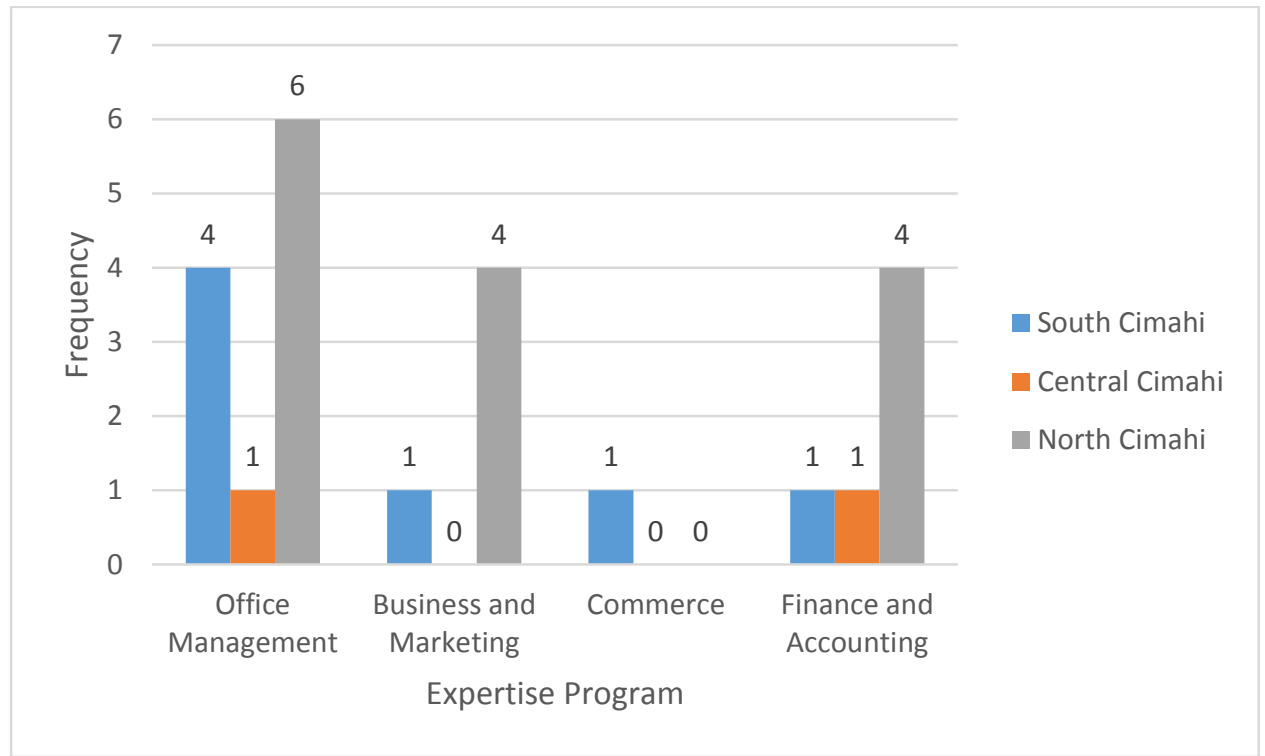

Source: Survey and data from http://dapo.dikdasmen.kemdikbud.go.id/) Figure 4. Distribution of business and management skills fields in Cimahi City vocational school (Per district)

In Figure 4 above, the Vocational Business and Management Vocational Fields in South Cimahi subdistricts is Office Management expertise (4 KK), in Cimahi Tengah subdistrict, office management and accounting and financial expertise programs have the same number of competencies, namely 1 (one), while in Cimahi Utara subdistrict it is the Office Management expertise $(6 \mathrm{KK})$.

Vocational Tourism Expertise in Cimahi sub-district can be seen in Figure 5 below: 


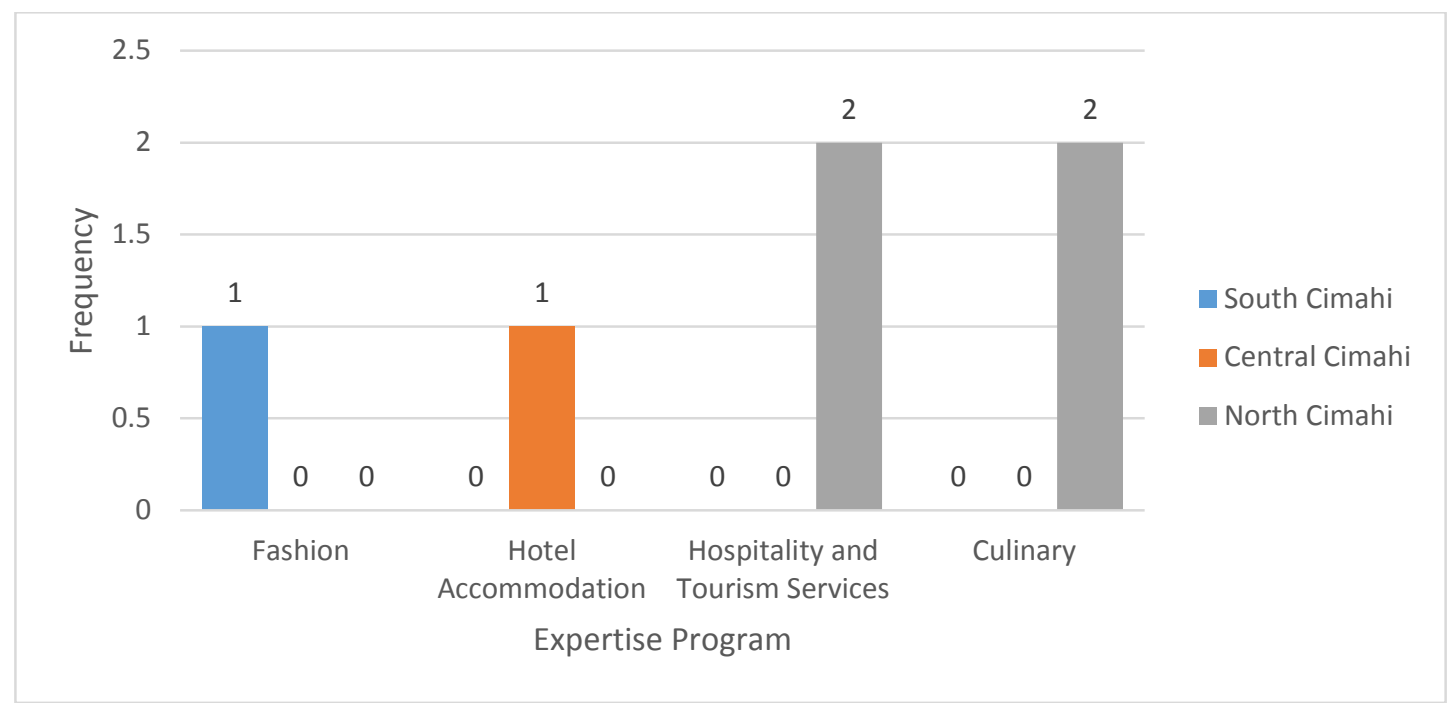

Source: Survey and data from http://dapo.dikdasmen.kemdikbud.go.id//)

Figure 5. Distribution of tourism expertise fields in Cimahi City vocational school (District)

In figure 5 above, the VOCATIONAL SCHOOL Tourism Expertise Sector in South Cimahi subdistricts is Fashion Management expertise (1 KK), in Cimahi Tengah subdistrict it is Hospitality Accommodation expertise ( $1 \mathrm{KK})$, while in the northern Cimahi subdistrict, Hospitality and Tourism Services expertise and Culinary has the same number of competencies, namely 2 (two).

Vocational Health and Social Work Expertise in Cimahi City can be seen in Figure 6 below:

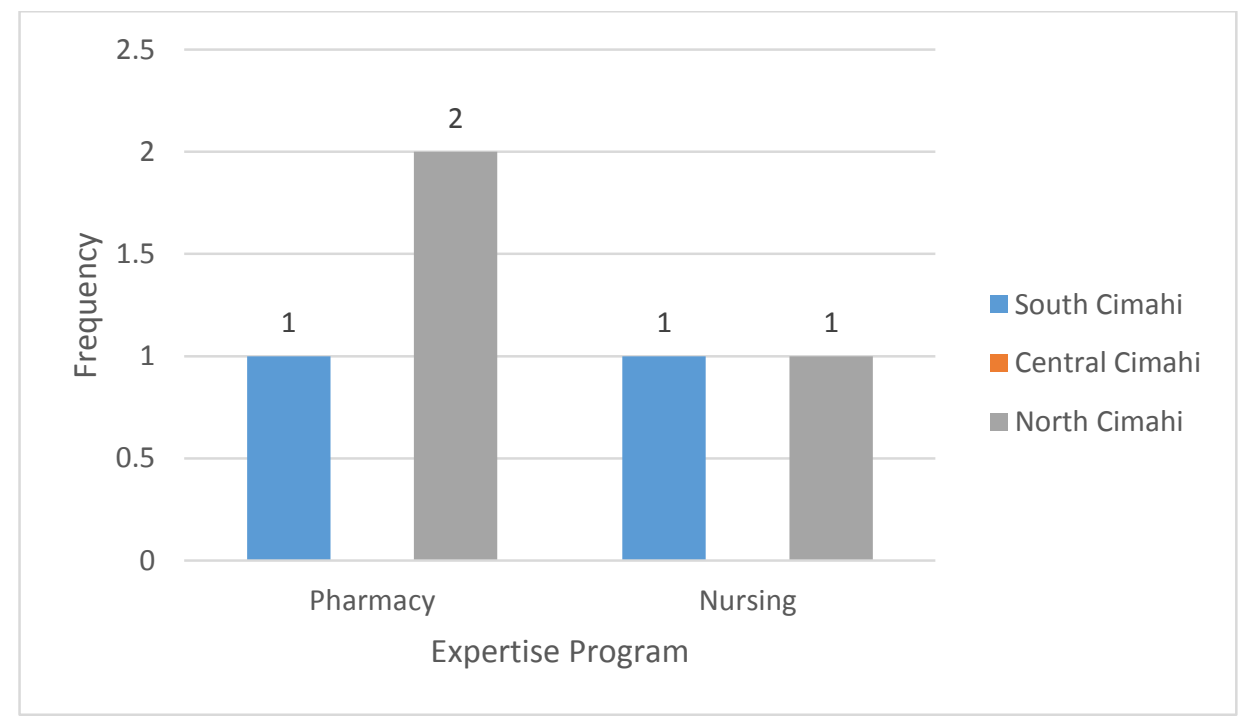

Source: Survey and data from http://dapo.dikdasmen.kemdikbud.go.id/)

Figure 6. Distribution of health and social work in Cimahi City vocational school (District)

In figure 6 above, the Vocational School Health and Social Work Skills Field in the Cimahi Selatan subdistrict is Pharmacy and Nursing expertise, 1 (one) Expertise Competency, in Cimahi Tengah Subdistrict, Health and Social Work Expertise program is absent, while in the North Cimahi subdistrict, Pharmacy's most expertise program is 2 Expertise Competencies. 
Field of Vocational Arts and Creative Industries in Cimahi City can be seen in figure 7 below:

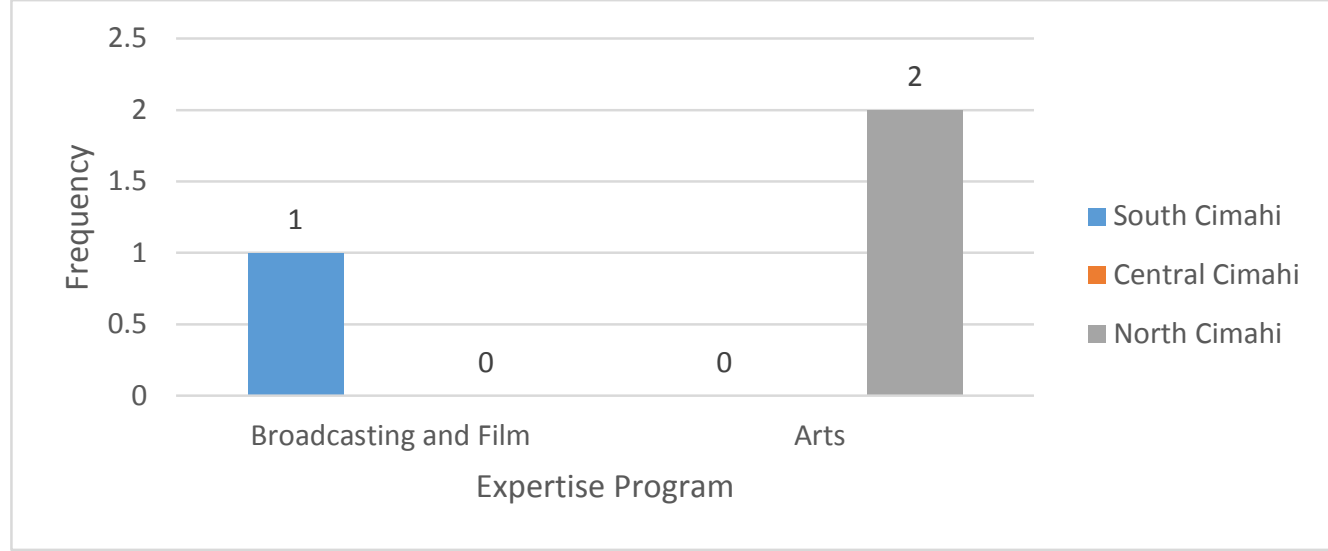

Source: Survey and data from http://dapo.dikdasmen.kemdikbud.go.id/)

Figure 7. Distribution of health and social work in Cimahi City vocational school (Per district)

In Figure 7 above, the Vocational Arts and Creative Industry Vocational Fields in the South Cimahi subdistrict is Broadcasting and Film Arts expertise program with 1 (one) Expertise Competency, in Cimahi Tengah subdistrict, Creative arts and industry expertise programs are absent, whereas in North Cimahi subdistrict, of the Fine Arts expertise program there are 2 Expertise Competencies.

Vocational Hospitality Expertise in Cimahi City can be seen in Figure 8 below:

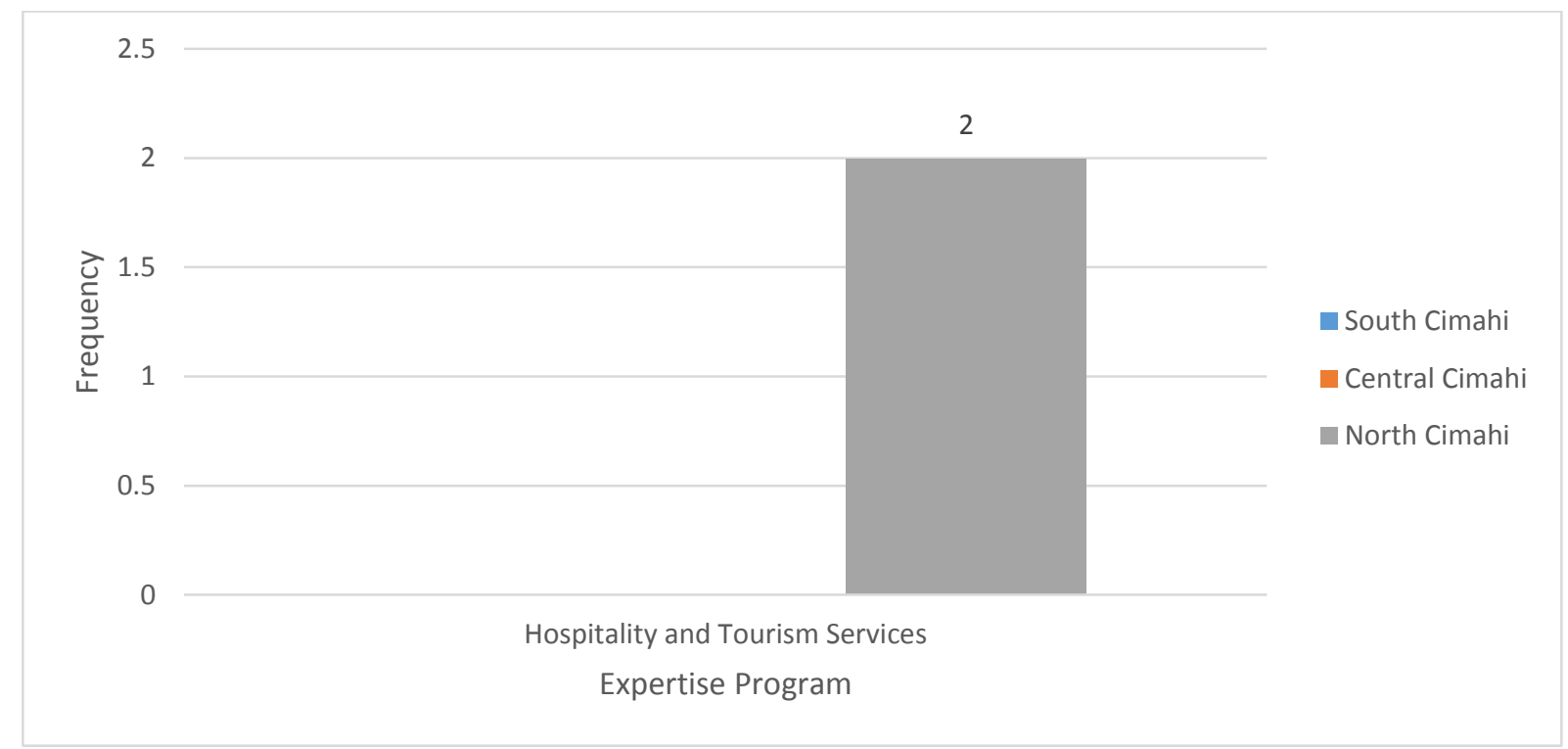

Source: Survey and data from http://dapo.dikdasmen.kemdikbud.go.id//)

Figure 8. Distribution of health and social work in Cimahi City vocational school (Per district)

In figure 8 above, the Vocational Hospitality Expertise Sector in South and Central Cimahi Districts are absent, while in the North Cimahi subdistrict, the Hospitality and Tourism Services expertise program has 2 Expertise Competencies. 
3.4 Analysis of vocational study program with industrial availability per district in Cimahi City

3.4.1 Vocational study program with industrial availability in South Cimahi District

South Cimahi District has an area of $16.2199 \mathrm{~km} 2$ consisting of 5 villages. The local potential of South Cimahi District is the availability of supporting facilities for agricultural activities in the form of agricultural production kiosks, rice barns and rice mills. In South Cimahi District, there are both traditional and modern markets. Nevertheless, the existence of economic facilities in the form of stalls and shops is spread in each subdistrict, even to the level of RW and RT. This can be seen in table 9 below (Source: BPS South Cimahi in 2018):

Table 9. Number of vocational schools and industries in South Cimahi district based on 2018 data

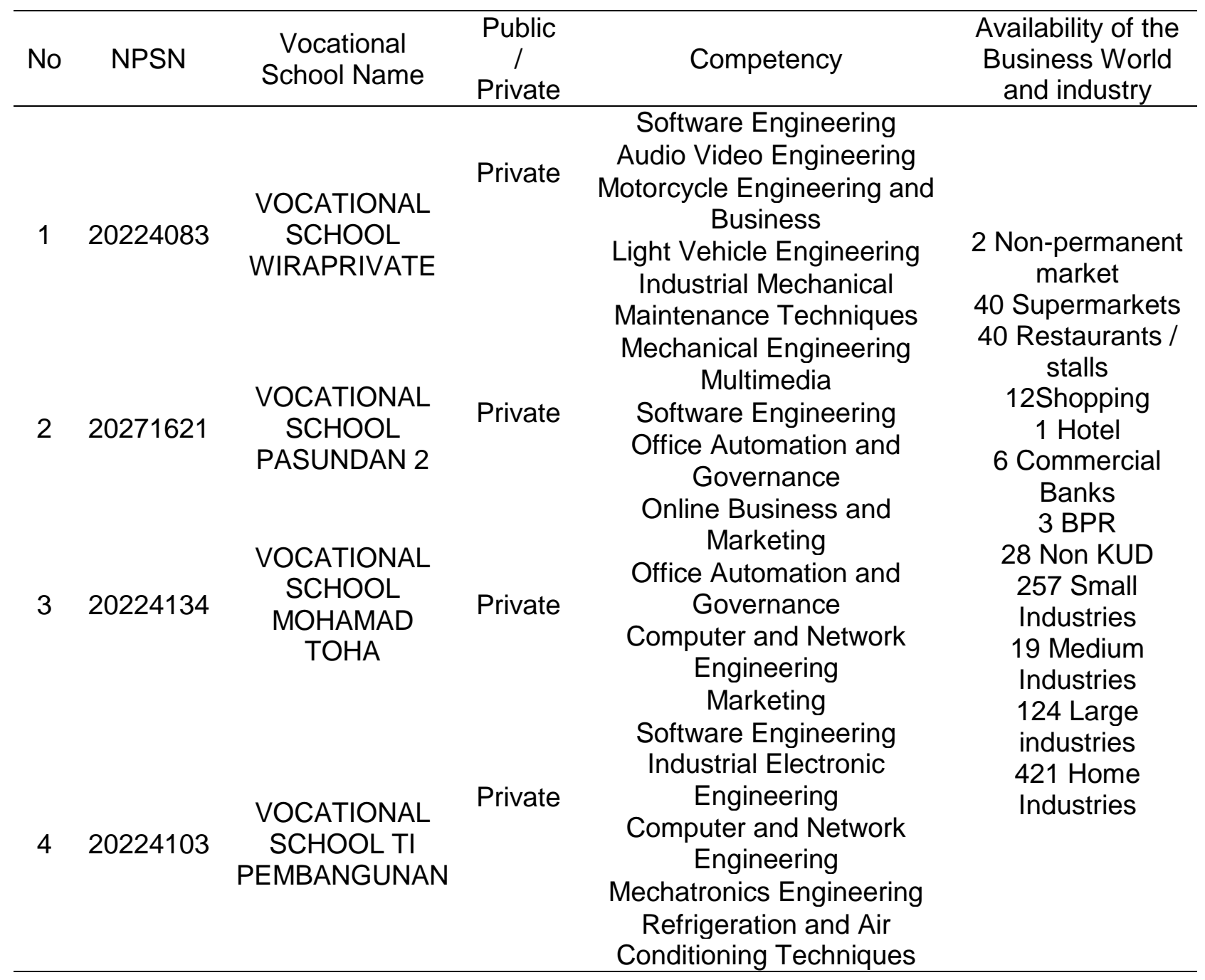


Table 9. Cont.

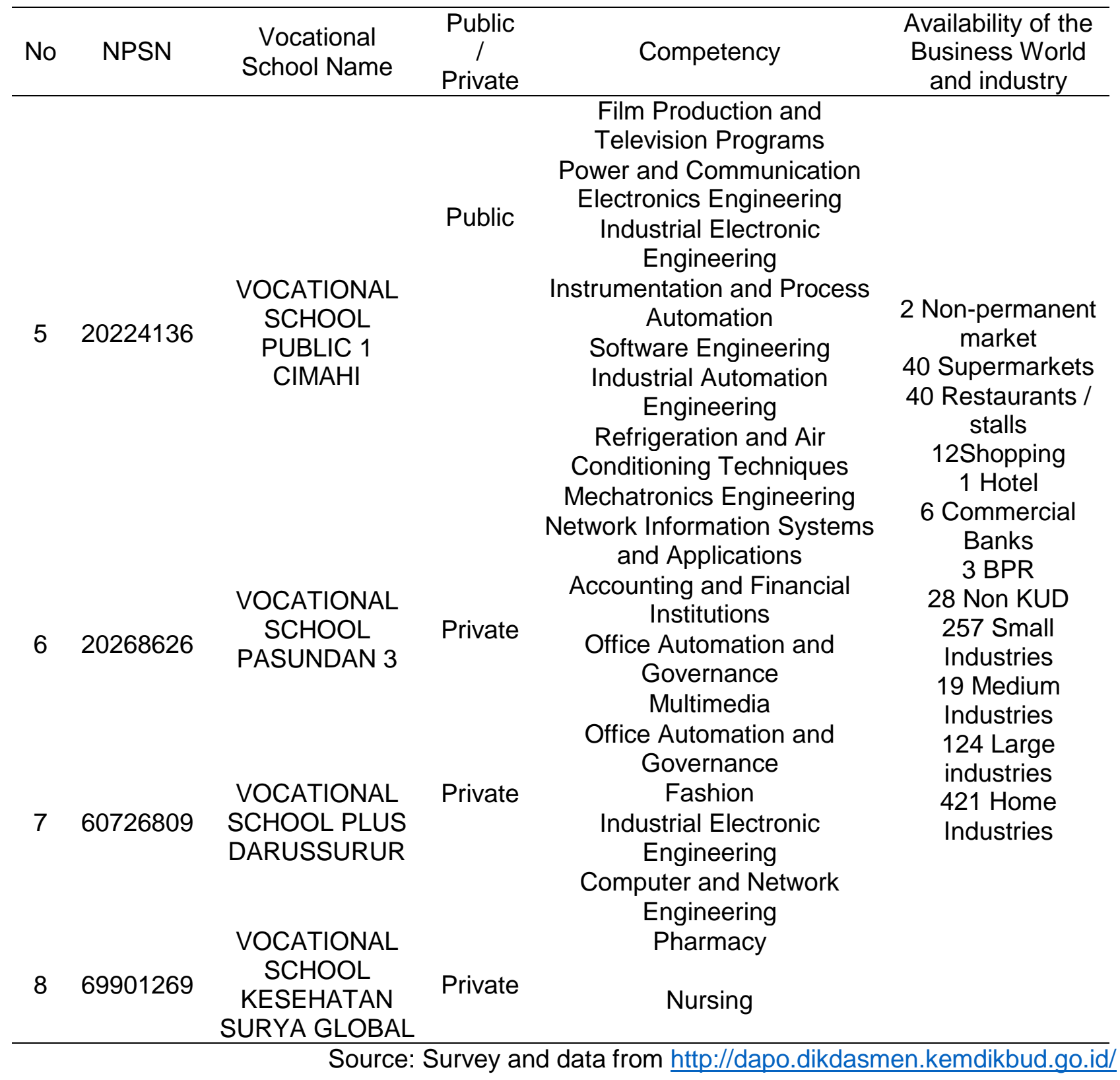

Based on table 9 above, Vocational Schools in South Cimahi District only have 8 public and private schools. Based on the results of a survey that has been done, it can be stated that the potential for the development of Vocational Schools in South Cimahi subdistrict based on local potential and industry readiness is the schools with the expertise in Engineering, considering the considerable industrial potential.

In addition, the area of business and management expertise has the potential to be developed, because the potential of supermarkets and financial institutions is quite adequate. 


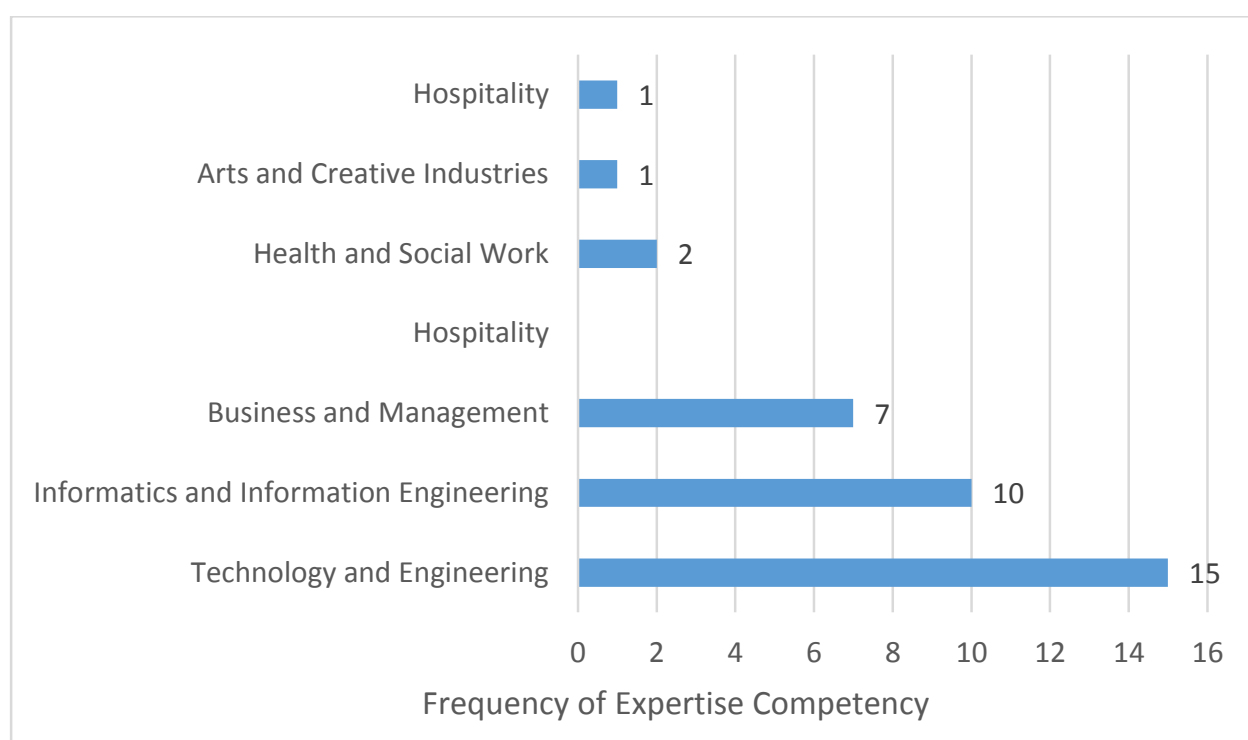

Source: Survey and data from http://dapo.dikdasmen.kemdikbud.go.id//

Figure 9. Distribution of vocational expertise programs in South Cimahi District

\subsubsection{Vocational study program with industrial availability in Central Cimahi District}

Central Cimahi Subdistrict has an area of $10.11 \mathrm{~km} 2$, consisting of 6 villages. The most jobs in Central Cimahi are in other fields at $41,48 \%$, and the least in agriculture which is $0.75 \%$. As shown in table 10 below.

Table 10. Number of working age population by village and employment sector in Central Cimahi District

\begin{tabular}{lll}
\hline Labor Sector & Number of Workers & Percentage \\
\hline Agriculture & 279 & $0.75 \%$ \\
Trading & 2918 & $7.80 \%$ \\
Services & 1836 & $4.91 \%$ \\
Army/Police & 5508 & $14.73 \%$ \\
Construction & 8799 & $23.53 \%$ \\
Industry / Craft & 2539 & $6.79 \%$ \\
Others & 15511 & $41.48 \%$ \\
\hline Total & 37390 & \\
\hline
\end{tabular}

Source: BPS Central Cimahi 2018

The number of Vocational Schools in Central Cimahi District is 4 private schools with 4 expertise programs, namely: Technology and Engineering, Information and Technology Engineering, Business and Management of Automotive Engineering for Light Vehicles and Tourism 
Table 11. Number of vocational schools and industries in Central Cimahi District

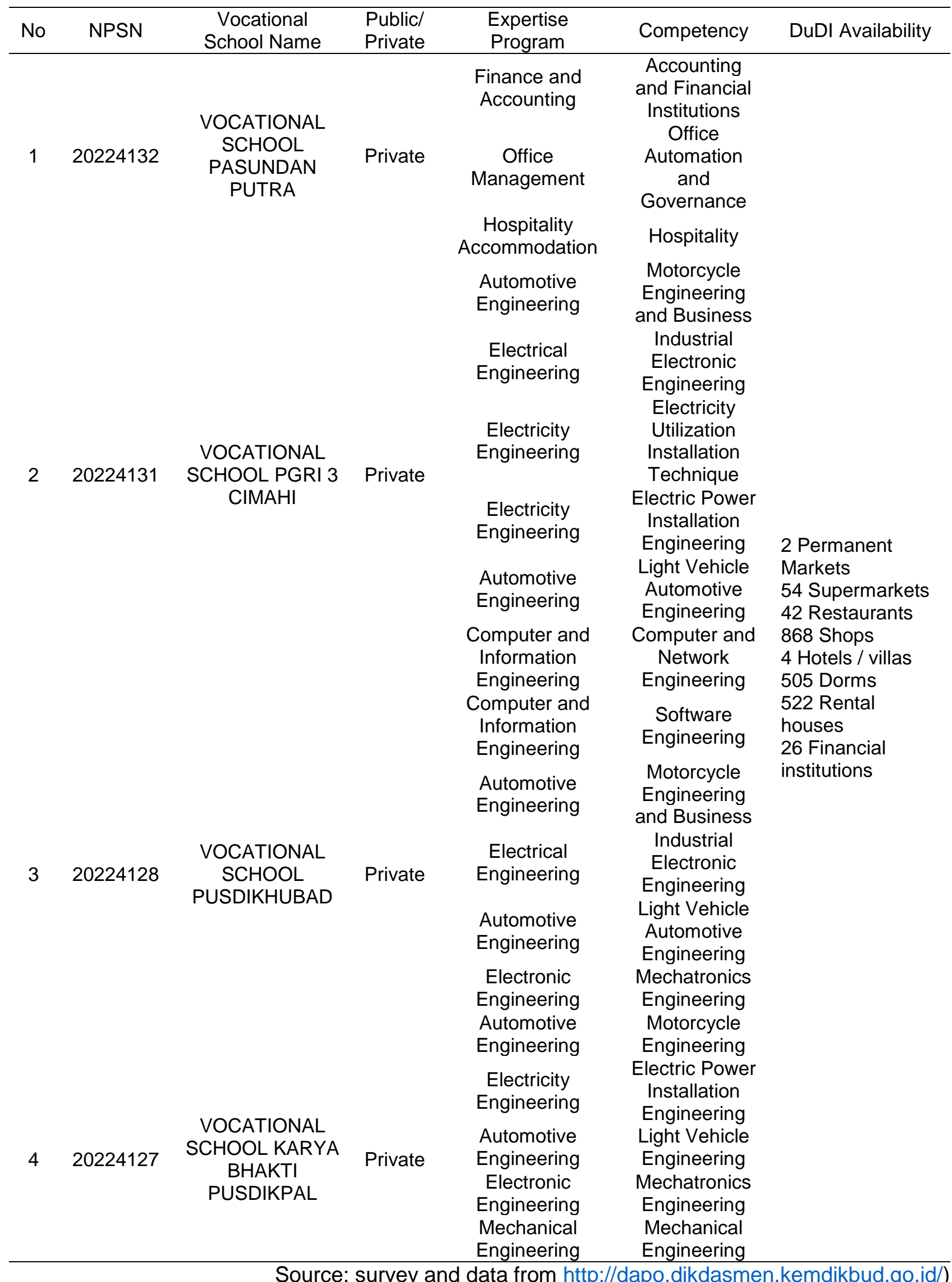


Based on table 11 above showing the survey results that have been carried out, it can be stated that the most local potential in Central Cimahi Subdistrict is the shopping complexes, thus that the development of vocational schools in the field of business and management expertise has a pretty good chance. Whereas Technology and Engineering expertise programs needs a little consideration, as the industry potential is small. The following is presented in Figure 10, showing the number of Expertise Programs and expertise competencies in Vocational Schools in Central Cimahi District:

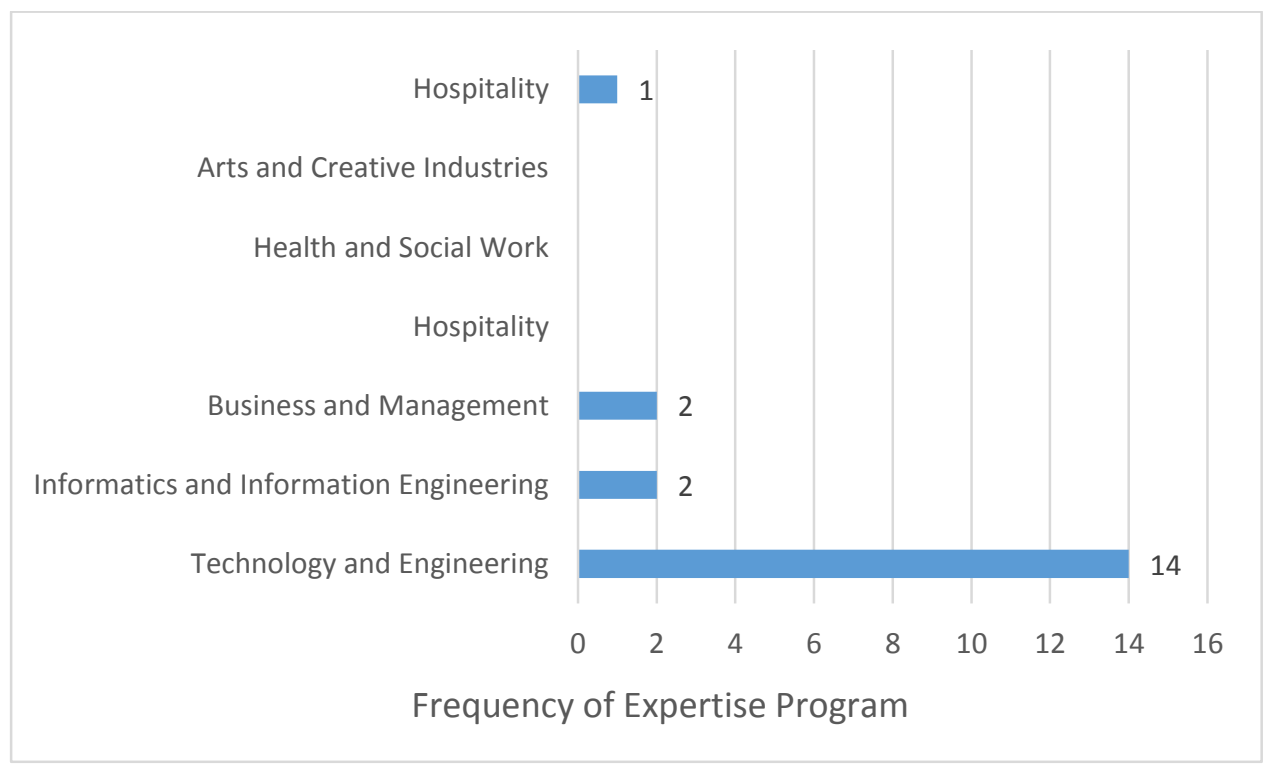

Figure 10. Distribution of vocational expertise in Middle Cimahi District in 2019

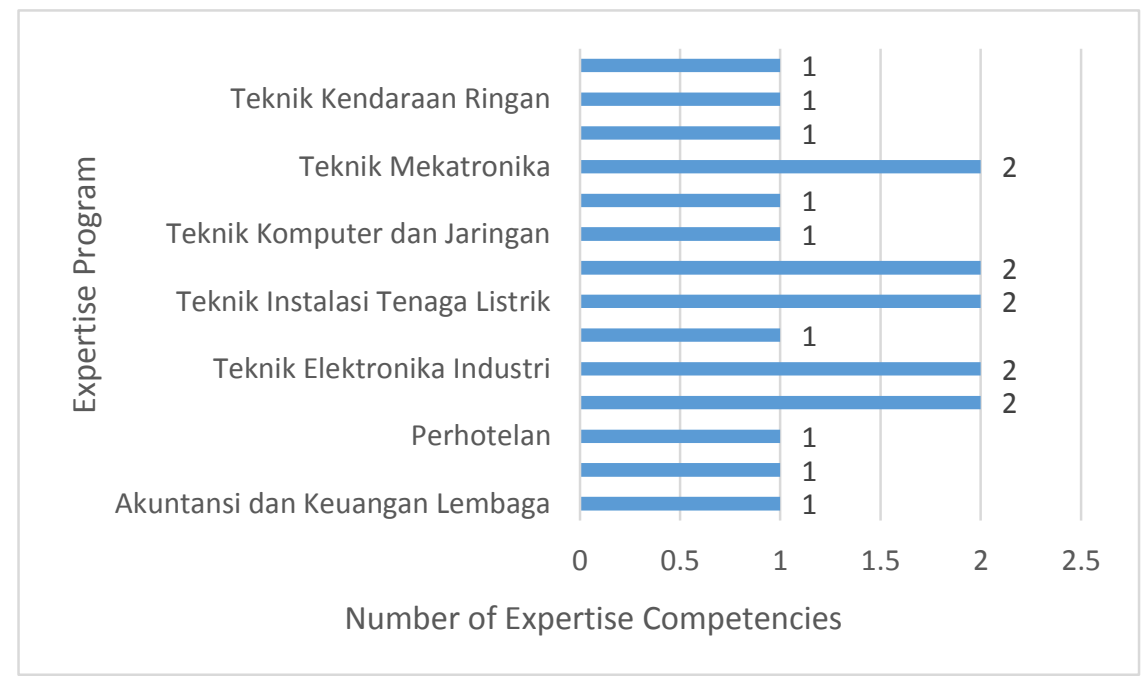

Figure 11. Distribution of vocational expertise competencies in Middle Cimahi District in 2019

\subsubsection{Vocational study program with industrial availability in North Cimahi District}

North Cimahi District has an area of $13.3 \mathrm{~km} 2$, consisting of 4 villages namely Pasir Kaliki, Citeureup, Cibabat and Cipageran. The local potential possessed by this subdistrict is industry, rice and secondary crops. Agricultural potential is quite good because the soil in North Cimahi District is fertile and easy to plant. The most jobs were in agriculture namely $41.65 \%$, trade $12.41 \%$, services 
$11.12 \%$ and industry $5.99 \%$ and other jobs at $28.83 \%$. The most potential of the business world is 82 food and beverage processing, 56 woven industries, 7 wood industries, 4 restaurants and 9 food stalls. Green tea is the most prominent processing product in Sindangkerta.

The number of Vocational Schools in North Cimahi District is 12 private / public schools. There are 7 Vocational Expertise Fields located in North Cimahi District namely Technology and Engineering, Information and Technology Engineering, Business and Management, Tourism, Health and Social Work, Arts and Creative Industries, and Hospitality.

Table 12. Number of vocational schools and industries in North Cimahi District

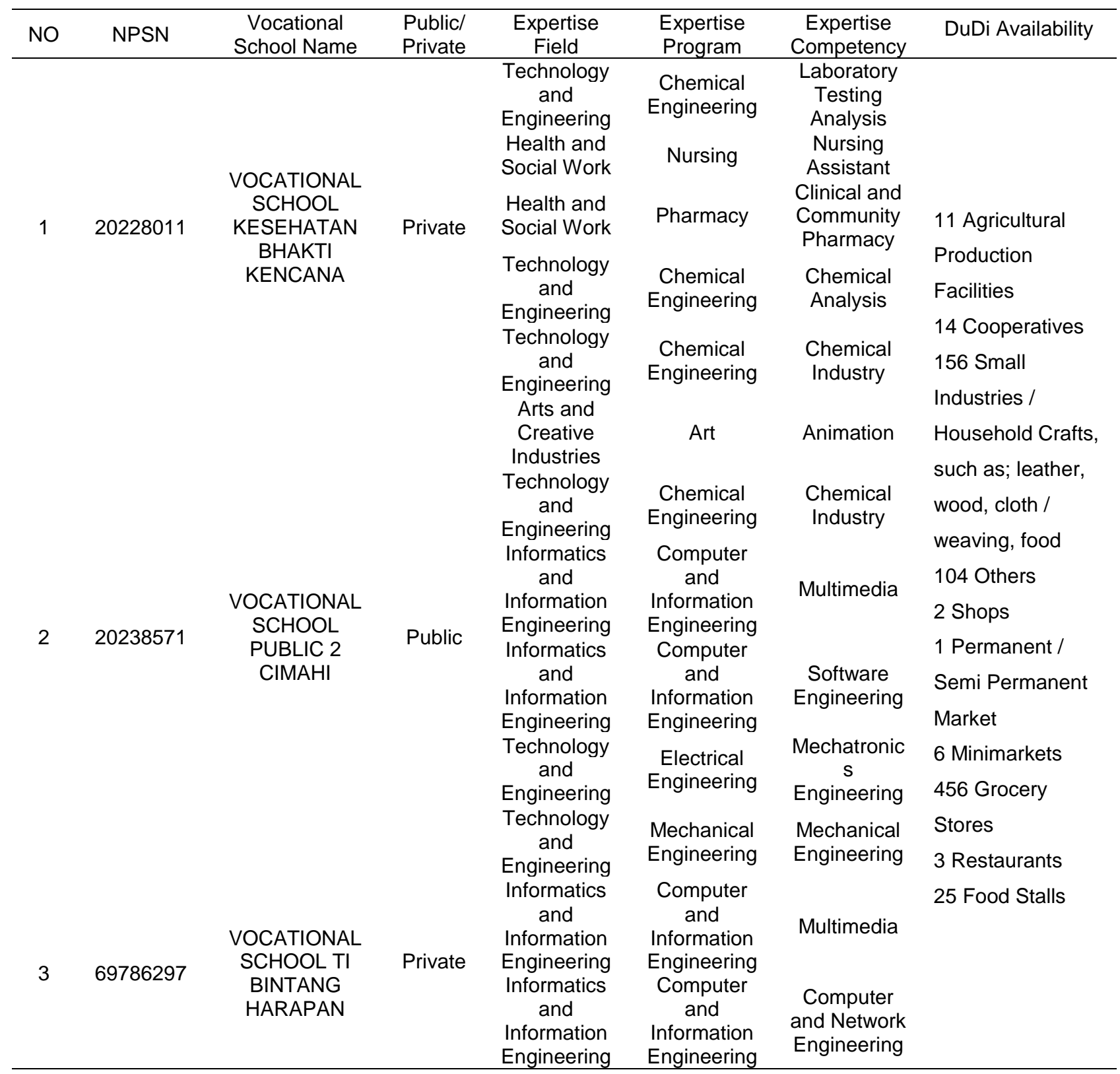


Table 12. Cont.

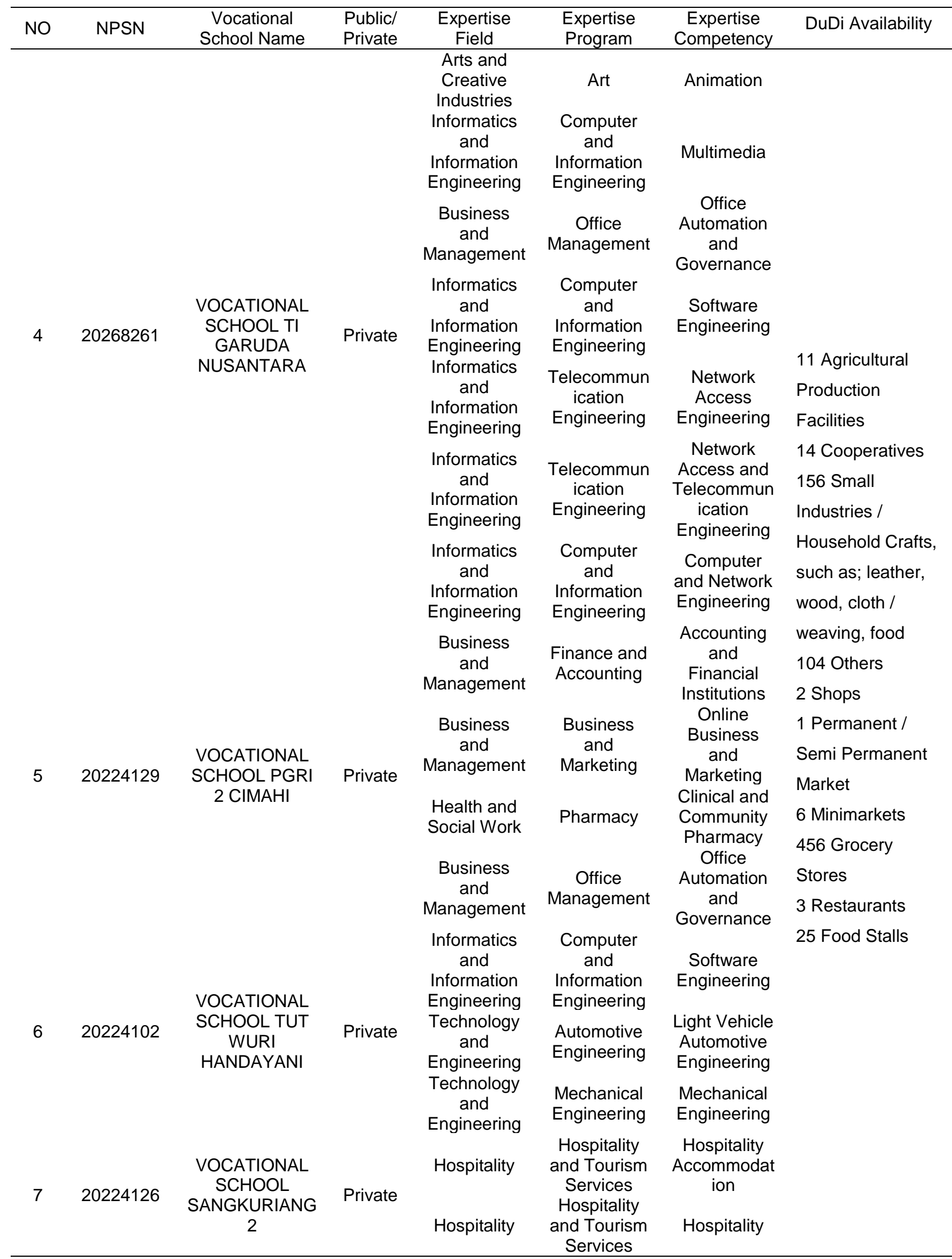


Table 12. cont.

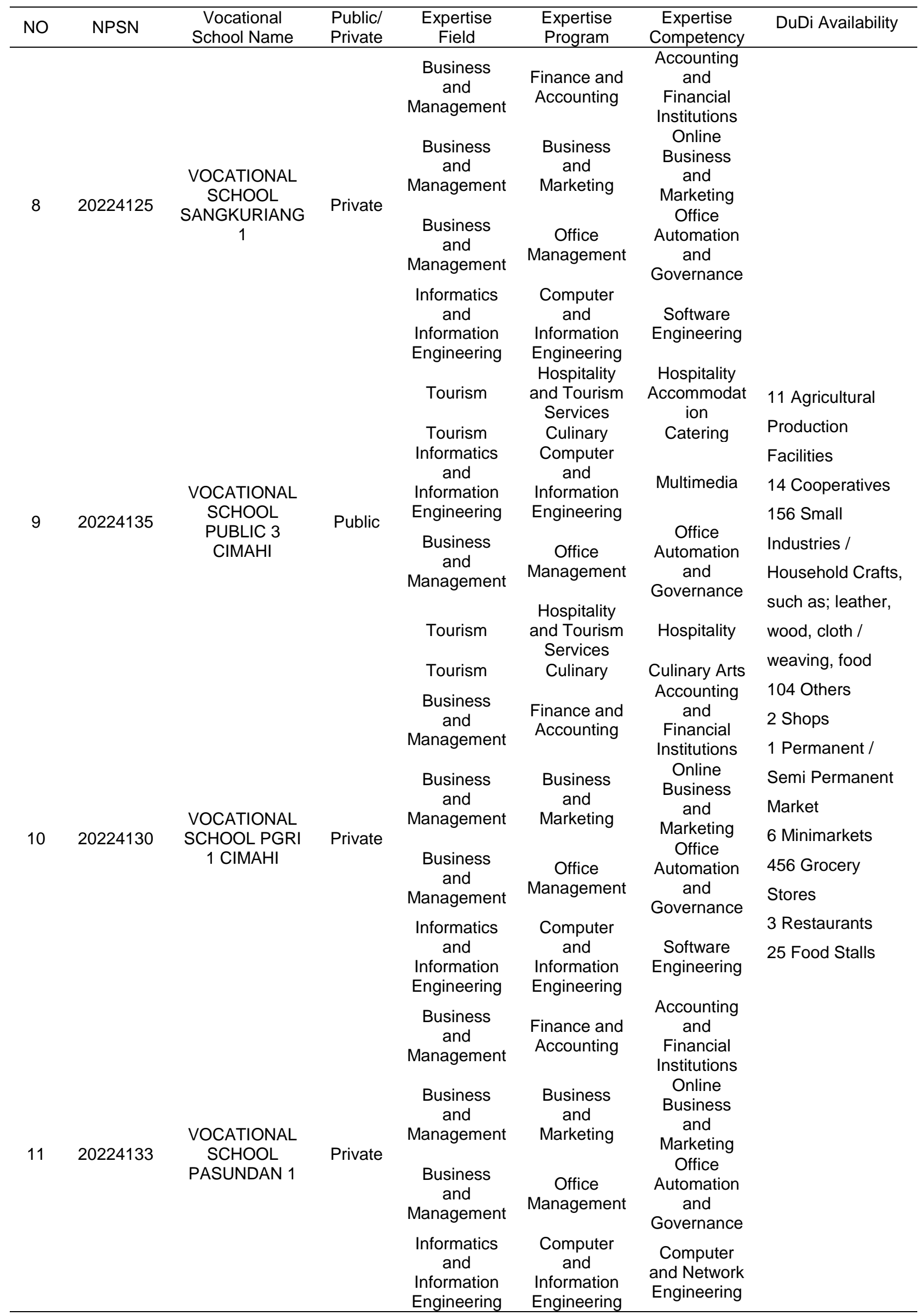


Table 12. Cont.

\begin{tabular}{|c|c|c|c|c|c|c|c|}
\hline NO & NPSN & $\begin{array}{c}\text { Vocational } \\
\text { School Name }\end{array}$ & $\begin{array}{l}\text { Public/ } \\
\text { Private }\end{array}$ & $\begin{array}{l}\text { Expertise } \\
\text { Field }\end{array}$ & $\begin{array}{l}\text { Expertise } \\
\text { Program }\end{array}$ & $\begin{array}{c}\text { Expertise } \\
\text { Competency }\end{array}$ & DuDi Availability \\
\hline \multirow{4}{*}{12} & \multirow{4}{*}{20224104} & \multirow{4}{*}{$\begin{array}{c}\text { VOCATIONAL } \\
\text { SCHOOL } \\
\text { TARUNA } \\
\text { MANDIRI }\end{array}$} & \multirow{4}{*}{ Private } & $\begin{array}{l}\text { Technology } \\
\text { and } \\
\text { Engineering }\end{array}$ & $\begin{array}{l}\text { Electricity } \\
\text { Engineering }\end{array}$ & $\begin{array}{l}\text { Electricity } \\
\text { Utilization } \\
\text { Installation } \\
\text { Technique }\end{array}$ & \\
\hline & & & & $\begin{array}{l}\text { Informatics } \\
\text { and } \\
\text { Information } \\
\text { Engineering }\end{array}$ & $\begin{array}{l}\text { Computer } \\
\text { and } \\
\text { Information } \\
\text { Engineering }\end{array}$ & Multimedia & \\
\hline & & & & $\begin{array}{l}\text { Technology } \\
\text { and } \\
\text { Engineering }\end{array}$ & $\begin{array}{l}\text { Mechanical } \\
\text { Engineering }\end{array}$ & $\begin{array}{l}\text { Mechanical } \\
\text { Engineering }\end{array}$ & \\
\hline & & & & $\begin{array}{l}\text { Technology } \\
\text { and } \\
\text { Engineering }\end{array}$ & $\begin{array}{l}\text { Automotive } \\
\text { Engineering }\end{array}$ & $\begin{array}{l}\text { Light Vehicle } \\
\text { Engineering }\end{array}$ & \\
\hline
\end{tabular}

Table 13. Number of vocational skills / competency programs of vocational expertise and availability of industrial and business world in North Cimahi District

\begin{tabular}{|c|c|c|}
\hline $\begin{array}{c}\text { Field of Expertise / Expertise } \\
\text { Program }\end{array}$ & $\begin{array}{l}\text { Number of } \\
\text { Expertise }\end{array}$ & DuDi Availability \\
\hline Technology and Engineering & Competencies & \\
\hline Electronic Engineering & 1 & \multirow{28}{*}{$\begin{array}{l}11 \text { Agricultural Production } \\
\text { Facilities } \\
14 \text { Cooperatives } \\
156 \text { Small Industries / Household } \\
\text { Crafts, such as; leather, wood, } \\
\text { cloth / weaving, food } \\
104 \text { Others } \\
2 \text { Shops } \\
1 \text { Permanent / Semi Permanent } \\
\text { Markets } \\
6 \text { Minimarkets } \\
456 \text { Grocery Stores } \\
3 \text { Restaurants } \\
\text { 25 Food Stalls }\end{array}$} \\
\hline Automotive Engineering & 2 & \\
\hline Mechanical Engineering & 3 & \\
\hline Electricity Engineering & 1 & \\
\hline Chemical Engineering & 4 & \\
\hline Total & 11 & \\
\hline \multicolumn{3}{|l|}{ Health and Social Work } \\
\hline Pharmacy & 2 & \\
\hline Nursing & 1 & \\
\hline Total & 3 & \\
\hline Business and Management & & \\
\hline Office Management & 6 & \\
\hline Business and Marketing & 4 & \\
\hline Finance and Accounting & 4 & \\
\hline Total & 14 & \\
\hline Tourism & & \\
\hline Hospitality dan Tourism Services & 2 & \\
\hline Culinary & 2 & \\
\hline Total & 4 & \\
\hline Hospitality & & \\
\hline Hospitality dan Tourism Services & 2 & \\
\hline $\begin{array}{l}\text { Total } \\
\text { Tol }\end{array}$ & 2 & \\
\hline Arts and Creative Industries & & \\
\hline Art & 2 & \\
\hline Total & 2 & \\
\hline $\begin{array}{l}\text { Informatics and Information } \\
\text { Engineering }\end{array}$ & & \\
\hline $\begin{array}{l}\text { Computer and Information } \\
\text { Enqineering }\end{array}$ & 13 & \\
\hline Telecommunication Engineering & 2 & \\
\hline Total & 15 & \\
\hline
\end{tabular}


From table 13 above, based on local potential and industry readiness, North Cimahi Subdistrict's the field of business and management expertise has a great opportunity to be developed. While hospitality expertise competencies are not yet needed in Vocational Schools, because North Cimahi Subdistrict does not yet have hotel facilities. In addition, the potential expertise programs developed is arts and creative industry expertise, because the potential of the home industry is quite adequate.

3.5 Analysis of vocational development in Cimahi City based on Principal Component Analysis (PCA)

Analysis of the level of vocational development in Cimahi City was carried out using the PCA calculation method. Educational indicators used as the basis for PCA calculation were Total Population Age 16-18 (X1), Student Ratio per School (X2), Student Ratio per Class (X3), Student Ratio per Teacher (X4), and Rough Participation Rate (APK/X5), which can be seen in the following table 14:

Table 14. Educational equity indicators by district in Cimahi City in 2019

\begin{tabular}{|c|c|c|c|c|c|c|c|c|c|}
\hline \multirow{2}{*}{ SWP } & \multirow{2}{*}{ District } & \multirow{2}{*}{$\begin{array}{c}\text { Total } \\
\text { Students }\end{array}$} & \multirow{2}{*}{$\begin{array}{l}\text { Population } \\
\text { Age 16-18 } \\
\text { (XI) }\end{array}$} & \multicolumn{3}{|c|}{ Student Ratio Per } & \multirow{2}{*}{$\begin{array}{l}\text { APK } \\
\text { (X5) }\end{array}$} & \multicolumn{2}{|c|}{$\begin{array}{c}\text { Ratio of High } \\
\text { Schools / Vocational } \\
\text { Schools }\end{array}$} \\
\hline & & & & $\begin{array}{c}\text { School } \\
\text { (X2) }\end{array}$ & $\begin{array}{c}\text { Class } \\
(\mathrm{X} 3)\end{array}$ & $\begin{array}{l}\text { Teacher } \\
(X 4)\end{array}$ & & $\begin{array}{l}\text { High } \\
\text { School }\end{array}$ & $\begin{array}{c}\text { Vocational } \\
\text { School }\end{array}$ \\
\hline 1 & $\begin{array}{l}\text { South } \\
\text { Cimahi }\end{array}$ & 6375 & 14258 & 796,88 & 25,71 & 24,24 & 44,71 & 5 & 8 \\
\hline 2 & $\begin{array}{l}\text { Central } \\
\text { Cimahi }\end{array}$ & 1927 & 8824 & 481,75 & 22,67 & 24,09 & 21,84 & 7 & 4 \\
\hline 3 & $\begin{array}{c}\text { North } \\
\text { Cimahi }\end{array}$ & 11203 & 9363 & 933,58 & 32,19 & 22,45 & 119,65 & 4 & 12 \\
\hline \multicolumn{2}{|c|}{ Total } & 19505 & 32445 & 2212,21 & 80,57 & 70,78 & 186,20 & 16 & 24 \\
\hline
\end{tabular}

Based on the indicators of educational equality, the lowest percentage of APK obtained for secondary education is in the Central Cimahi District, which is $21.84 \%$.

One of the benefits of Principal Component Analysis (PCA) is to set priorities for handling things that are more basic than the structure of the problems faced, so that the efficiency and effectiveness of problem handling can be further improved (Dermoredjo \& Noekman, 2009; Dermoredjo 2017). PCA was used as an analysis to determine the priority of Vocational Development with the PCA method, based on the education indicators of each district used, it was possible to know the location in which Vocational School was prioritized, determining priority points by looking at the smallest score of PCA 1 (Dermoredjo \& Noekman, 2009). The results of PCA 1 calculations using the Minitab Statistical Software version 14 can be seen in table 15 below: 
Table 15. PCA score 1 for each district

\begin{tabular}{|c|c|c|c|c|c|c|c|c|c|c|c|}
\hline \multirow[t]{2}{*}{ SWP } & \multirow[t]{2}{*}{ District } & \multirow{2}{*}{$\begin{array}{c}\text { Total } \\
\text { Students }\end{array}$} & \multirow{2}{*}{$\begin{array}{l}\text { Population } \\
\text { Age 16-18 } \\
\text { (XI) }\end{array}$} & \multicolumn{3}{|c|}{ Student Ratio Per } & \multirow{2}{*}{$\begin{array}{l}\text { APK } \\
\text { (X5) }\end{array}$} & \multicolumn{2}{|c|}{$\begin{array}{c}\text { Ratio of High } \\
\text { Schools / } \\
\text { Vocational } \\
\text { Schools } \\
\end{array}$} & \multirow[b]{2}{*}{$\begin{array}{l}\text { PCA } \\
\text { Score }\end{array}$} & \multirow{2}{*}{$\begin{array}{c}\text { Informati } \\
\text { on }\end{array}$} \\
\hline & & & & $\begin{array}{c}\text { School } \\
\text { (X2) }\end{array}$ & $\begin{array}{c}\text { Class } \\
\text { (X3) }\end{array}$ & $\begin{array}{l}\text { Teacher } \\
\text { (X4) }\end{array}$ & & $\begin{array}{l}\text { High } \\
\text { School }\end{array}$ & $\begin{array}{c}\text { Vocation } \\
\text { al } \\
\text { School }\end{array}$ & & \\
\hline 1 & $\begin{array}{l}\text { South } \\
\text { Cimahi }\end{array}$ & 6375 & 14258 & 796,88 & 25,71 & 24,24 & 44,71 & 5 & 8 & $\begin{array}{c}- \\
1026,0 \\
2\end{array}$ & Priority I \\
\hline 2 & $\begin{array}{l}\text { Central } \\
\text { Cimahi }\end{array}$ & 1927 & 8824 & 481,75 & 22,67 & 24,09 & 21,84 & 7 & 4 & 644,19 & Priority II \\
\hline 3 & $\begin{array}{l}\text { North } \\
\text { Cimahi }\end{array}$ & 11203 & 9363 & 933,58 & 32,19 & 22,45 & 119,65 & 4 & 12 & $-435,5$ & $\begin{array}{c}\text { Priority } \\
\text { III }\end{array}$ \\
\hline \multicolumn{2}{|c|}{ Total } & 19505 & 32445 & 2212,21 & 80,57 & 70,78 & 186,20 & 16 & 24 & & \\
\hline
\end{tabular}

Based on table 15 above, the education indicators, the lowest PCA 1 score obtained for the three districts is in the District of South Cimahi $(-1026.02)$. This means that the priority location for the development of VOCATIONAL SCHOOL is South Cimahi District. Then followed by Central Cimahi Subdistrict (-644.19) became priority location II for the development of VOCATIONAL SCHOOL. And Priority III is the District of North Cimahi (-435.5).

Eigenvalue values for the five components can be seen in Figure 12 below. The factoring process is stopped at components with eigenvalue value below $1(0.0000)$. Eigenvalue is the value of the main component variant (Principal Component, PC).

\begin{tabular}{|c|c|c|c|c|c|}
\hline Eigenvalue & 3,6980 & 1,3020 & 0,0000 & 0,0000 & $-0,0000$ \\
\hline Proportion & 0,740 & 0,260 & 0,000 & 0,000 & $-0,000$ \\
\hline Cumulative & 0,740 & 1,000 & 1,000 & 1,000 & 1,000 \\
\hline
\end{tabular}

Figure 12. Eigenvalue (MINITAB output)

In Figure 12 above, the Eigenvalue (Output) values shows the eigenvalues for the first (PC1) and second (PC2) main components as 3.6980 and 1.3020. Eigenvalue of the two main components represents $74.0 \%$ and $26.0 \%$ of all variability's. When accumulated, the two main components represent $100 \%$ of the total variability. This means that if the five variables are reduced to 2 variables, then both variables can already explain $100 \%$ of the total variability. Next the score for the PCA component can be seen in the component matrix in Figure 13 below:

$\begin{array}{llrrrrr}\text { Variable } & & \text { PC1 } & \text { PC2 } & \text { PC3 } & \text { PC4 } & \text { PC5 } \\ \text { Penduduk Usi 16-18 (XI) } & -0,099 & -0,860 & -0,120 & 0,450 & -0,183 \\ \text { Sekolah (X2) } & & 0,455 & -0,425 & -0,037 & -0,467 & 0,627 \\ \text { Kelas (X3) } & & 0,519 & -0,067 & -0,266 & -0,376 & -0,717 \\ \text { Guru (X4) } & & -0,494 & -0,273 & 0,540 & -0,581 & -0,227 \\ \text { APK (X5) } & & 0,520 & 0,014 & 0,789 & 0,317 & -0,085\end{array}$

Figure 13. Matrix component 
In Figure 13 above, the score for the component formed can be calculated by looking at the coefficient values for each variable. For PC1 component with an eigenvalue, the score can be calculated as follows:

$$
\begin{gathered}
\text { PC1 }=-0,099 \text { population aged } 16-18 \text { years }+0.455 \text { School }+0.519 \text { Class }-0.494 \text { Teacher }+0.520 \\
\text { APK }
\end{gathered}
$$

The second component (PC2) has an eigenvalue of 1.3020 and can explain 26.0 percent diversity. Together with the first component (PC1), both represent 100 percent of total diversity. Scores for PC2 are calculated as follows:

$$
\text { PC2 }=-0,860 \text { Population age 16-18 }-0.425 \text { School }-0.067 \text { Class }-0.273 \text { Teacher }+0.014 \text { APK }
$$

Determination of the number of components to be used is very subjective. In this case, the two components of PC1 and PC2 that represent 100 percent of total diversity can be judged to be sufficient to capture the data structure, even using only the first component is sufficient to capture the data structure by looking at the criteria for an eigenvalue value greater than 1 . Other components having a small proportion of diversity can be considered insignificant. This can be seen in Figure 14 below.

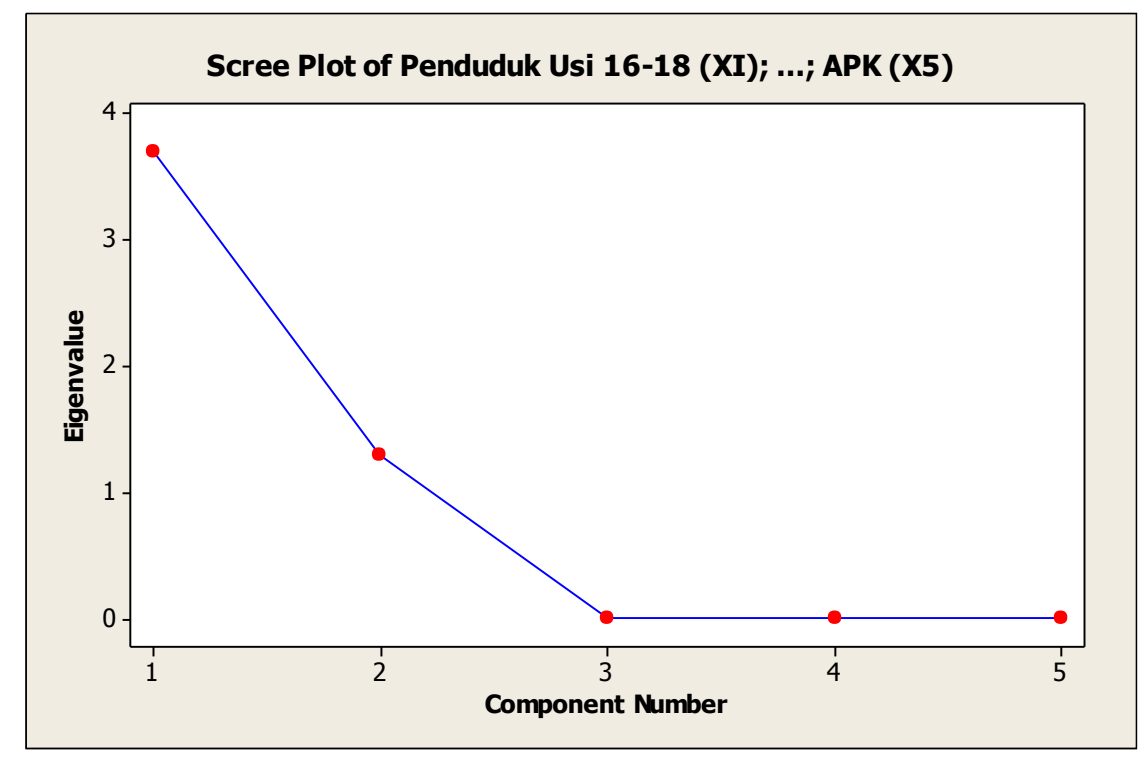

Figure 14. Scree plot

From the scree plot, it can be seen that eigenvalue above 1 is only 2 . This proves that only two factors can be formed. 


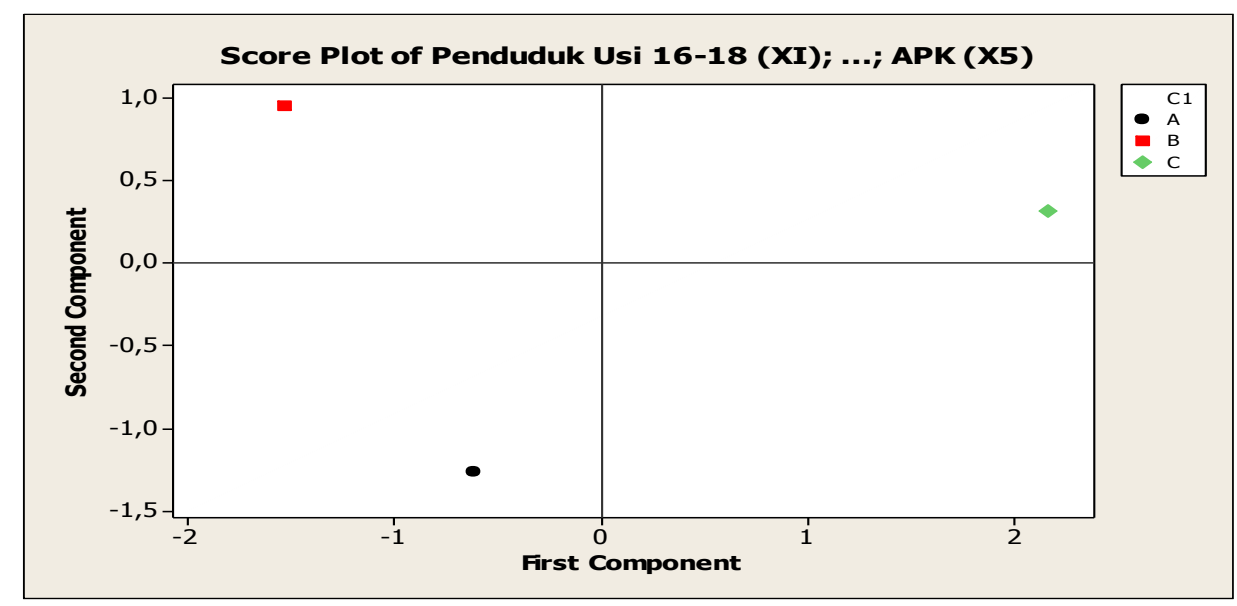

Figure 15. Score plot

In Figure 15 above, it can be seen in the score plot that eigenvalue which above 0.0 have 2 components. This proves that only two factors can be formed, namely PC1 and PCA 2.

\section{Conclusion}

Regional potentials in Cimahi City are mostly industrial areas, prominent economic potentials are office potential, home industry/ craft, creative industry, and food/ beverage processing. The main finding of this study is that there are still gaps between vocational school vocational expertise programs in Cimahi City that are not in accordance with the availability of industry in each district. Findings from the results of the Location Quotient (LQ) analysis show that the potential of the Cimahi City area that has basic criteria (LQ> 1) are the processing industry, construction, wholesale and retail trade, car and bicycle repairs, Information and Communication, Financial Services and Insurance, Government Administration, Mandatory Defense and Social Security, Educational Services, and Health Services and Social Activities. This means that the development of vocational schools can be directed at the field / program / competency of expertise in accordance with the potential of the area above. The findings based on Principle Component Analysis (PCA) show that the development of CMS in Cimahi City that becomes priority I is that Vocational Schools in Cimahi Selatan subdistrict are to obtain a PCA score of -1026.02 . then followed by Central Cimahi District (-644.19), which became priority location II, and North Cimahi District (-435.5) as Priority III.

\section{References}

Amalia, F. (2018). Analisis Lulusan Pendidikan Menengah kejuruan Dikaitkan dengan Pengembangan Wilayah Kota Medan. [Online]. Retrieved from: http://repositori.usu.ac.id/handle/123456789/12291

Badan Pusat Statistika. (2018). Jawa Barat dalam Angka 2018. Jawa Barat: Badan Pusat Statistika. 
Badan Pusat Statistika. (2018). Cimahi dalam Angka 2018. Cimahi: Badan Pusat Statistika. [Online]. Retrieved from: https://cimahikota.bps.go.id/publication/2018/08/16/1874f10fced480d7cd2edaa0/kotacimahi-dalam-angka-2018.html

Badan Pusat Statistika. (2018). Cimahi Selatan dalam Angka 2018. Cimahi: Badan Pusat Statistika.

Badan Pusat Statistika. (2018). Cimahi Tengah dalam Angka 2018. Cimahi: Badan Pusat Statistika.

Badan Pusat Statistika. (2018). Cimahi Utara dalam Angka 2018. Cimahi: Badan Pusat Statistika.

Dapodikdasmen. (2019). Data Sekolah Kota Cimahi. [Online]. Retrieved from: http://dapo.dikdasmen.kemdikbud.go.id/sp/2/026700

Meirawan, D., Ana, A., and Saripudin, S. (2018). Priority of VHS Development Based in Potential Area using Principal Component Analysis. IOP Conference Series: Materials Science and Engineering, 306(1), 012027.

Dermoredjo, S. K. (2017). Analisis kebijakan hubungan antarsektor perekonomian nasional. Analisis Kebijakan Pertanian, 1(4), 345-362.

Dermoredjo, S. K., and Noekman K. (2009). Analisis Penentuan Indikator Utama Pembangunan Sektor Pertanian di Indonesia: Pendekatan analisis Komponen Utama. SOCA: Jurnal Sosial Ekonomi Pertanian, 1-26.

Enoch, J. (1995). Dasar-dasar perencanaan pendidikan. Jakarta: Penerbit Bumi Aksara.

Mayuni, P. A., and Sukerti N. W. (2016). Optimalisasi Peran Dunia Usaha Dan Industri (Dudi) dalam Pengembangan Profesionalisme Guru VOCATIONAL SCHOOL Secara Berkelanjutan. Prosiding Seminar Nasional Dalam Rangka Konvensi Nasional VIII dan Asosiasi Pendidikan Teknologi dan Kejuruan Indonesia (APTEKINDO) dan Temu Karya XIX FT/FPTK-JPTK se Indonesia, ISBN: 978-602-74864-0-9. Penerbit: Fakultas Teknik Universitas Public Medan.

Sudjani. (2016). Pengembangan Program Praktek Kerja Industri (Prakerin) Dalam Implementasi Kurikulum VOCATIONAL SCHOOL 2013. Prosiding Seminar Nasional dalam Rangka Konvensi Nasional VIII dan Asosiasi Pendidikan Teknologi dan Kejuruan Indonesia (APTEKINDO) dan Temu Karya XIX FT/FPTK-JPTK se Indonesia, ISBN: 978-602-748640-9, Penerbit: Fakultas Teknik Universitas Public Medan.

Undang-Undang Nomor 20 Tahun 2003 tentang Pendidikan Sistem Nasional. 